\title{
土木学会論文報告集
}

第 264 号・1977 年 8 月

\section{安家川鉄道橋（上路型プレストレストコンクリート \\ トラス橋）の設計・施工 \\ AKKAGAWA RAILWAY BRIDGE (DECK-TYPE PRESTRESSED \\ CONCRETE TRUSS BRIDGE)}

松本䕒司* - 斉藤 俊彦** • 三浦一郎*** - 峯 好 武****

By Yoshiji MATSUMOTO, Toshihiko SAITO, Ichiro MIURA

and Yoshitake MINE

表-1 橋梁形式の比較

\section{1. まえがき}

\begin{tabular}{|c|c|c|c|c|c|c|}
\hline & 梁 & 形成 & & 成 & & 備 \\
\hline 上路フ & คレー & トガータ & - & $7.0 \mathrm{~m} \times 1+31.3 \mathrm{~m} \times 7+16.0 \mathrm{~m} \times 1$ & $l=311.87 \mathrm{~m}$ & \multirow{8}{*}{ 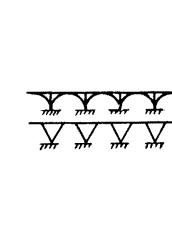 } \\
\hline 鋼 製 & 単 純 & 忳卜ラ & ス & $12.9 \mathrm{~m} \times 2(\mathrm{DG})+56.8 \mathrm{~m}(\mathrm{DT}) \times 5$ & $l=314.8 \mathrm{~m}$ & \\
\hline $\mathrm{PC}$ & 単 & 純 & 标 & $46.0 \mathrm{~m} \times 7$ & $l=322.4 \mathrm{~m}$ & \\
\hline $\mathrm{PC}$ & 箱 & & 析 & $55.0 \mathrm{~m} \times 6$ & $l=332.2 \mathrm{~m}$ & \\
\hline $\mathrm{PC}$ & 連 & 続 箱 & 标 & $55.0 \mathrm{~m} \times 6$ & $l=332.0 \mathrm{~m}$ & \\
\hline $\mathrm{R} \mathrm{C}$ & $\boldsymbol{\jmath}$ & - & 于 & $24.5 \mathrm{~m} \times 1+80 \mathrm{~m} \times 2+75 \mathrm{~m} \times 1+35 \mathrm{~m} \times 1$ & $l=299.5 \mathrm{~m}$ & \\
\hline R C & $\pi$ ラ & $5-x$ & ע & $60 \mathrm{~m} \times 3+45 \mathrm{~m} \times 1+30 \mathrm{~m} \times 1$ & $l=300.5 \mathrm{~m}$ & \\
\hline $\mathrm{PC}$ & r & j & x & $27.0 \mathrm{~m} \times 1+45.0 \times 6$ & $l=305.06 \mathrm{~m}$ & \\
\hline
\end{tabular}

日本鉄道建設公団で 建設中の久慈線は, 岩 手県久慈市と宮古市を 結ぶ延長 $71 \mathrm{~km} の$ 新 線で，陸中海岸国立公 園を綐断し，現在建設

中の気仙沼線・盛線とあわせて三陸縦貫鉄道の一貫をな 寸ものである. 安家川橋梁はこの久慈線建設工事におい て, 久慈起点 $18.490 \sim 18.795 \mathrm{~km}$ 間の安家川を渡る 約 $305 \mathrm{~m}$ の橋梁である. 本地点は安家川の河口にあたり, また計画高が河床より約 $40 \mathrm{~m}$ と非常に高い位置に設け られているために, 構造物は常に塩分を含んだ風を受け ることになる. 安家川橋梁に対しては, 上記の架設条件

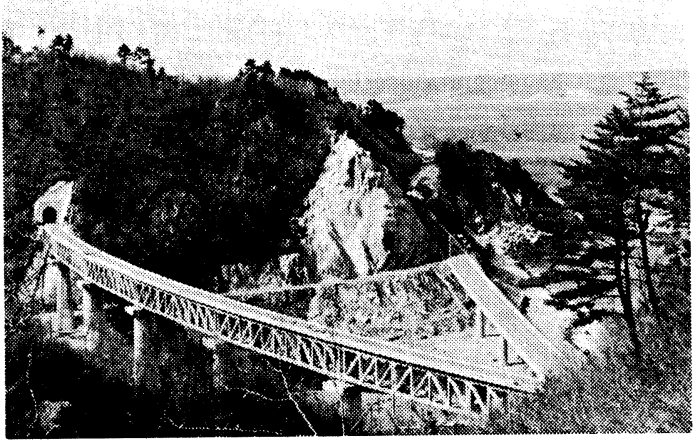

写真-1 安家川橋梁全景

* 正会員 工博 東京大学教授 工学部土木工学科

** 正会員 戸田建設(株)取締役（前日本鉄道建設公団盛岡 支社長)

*** 正会員 工博 日本コンクリート工業(株)取締役

**** 正会員 オリエンタルコンクリート(株)仙台支店 工務 部長
を考慮して，コンクリート構造でかつなるべく死荷重の 小さな橋梁形式とし, 工場製作による超高強度コンクリ 一ト $\left(\sigma_{c k}=800 \sim 1000 \mathrm{~kg} / \mathrm{cm}^{2}\right)$ を利用した 新しい形式 の PCトラスを建設することにした.

本論文はこの安家川橋梁上部工の設計・施工の概要に ついで述べたものである.

\section{2. 橋梁の概要}

安家川橋梁の 構造形式を 選定するにあたっては, (1) 現地に適合し, かつ環境・公害問題を考慮した構造形式 であること, (2) 海岸に近いという綮しい立地条件にあ るので, 保守上有利なコンクリート構造とすること, (3) 国立公園内にあるので付近の地形との調和のとれた美観 上良好な構造形式であること，といら基本方針に基づい て表一1 に示寸計画案を対象に, 比較検討が行われた が, その結果, 将来のコンクリート橋として長大化の可 能性が高い PCトラス橋を採用することにした.

コンクリート構造でトラスを構成することは, 古くは Paris 東駅構内の La Fayette 橋 (スパン $71.87 \mathrm{~m}+$ $76.85 \mathrm{~m}, 1928$ 年), Ivry 橋 (スパン $32.3 \mathrm{~m}+134.63 \mathrm{~m}$ $+47.7 \mathrm{~m}, 1930$ 年), Montrose の South Esk 川橋( ス パン $45 \mathrm{~m}+65 \mathrm{~m}+45 \mathrm{~m}, 1931$ 年) などがあり, 新しい 
ものにはプレストレストコンクリートを用い た Mangfall 橋 (スパン $90 \mathrm{~m}+108 \mathrm{~m}+90 \mathrm{~m}$, 1959 年), Zaza 川橋 (中央スパン $90 \mathrm{~m}, 1959$ 年）があるが, Zaza 川橋以外はいずれも場所 打ち施工のコンクリートトラスである. 鉄筋コ ンクリートのトラスに対しては, 1932 年の第 1 回構造工学大会でも討論されており, 網状ひ びわれが発生すること, 施工上の困難を伴うことなどの 問題点が指摘されている. Mangfall 橋のようにプレス トレストコンクリートとすればひびわれの発生は防止で きるが, なお施工上の問題点が残されている.これらの ことを考えて, ここでは工場製作の超高強度コンクリー トによるプレキャスト部材を用いたプレストレストコン クリート構造のトラスを設計し, その施工を通じて長大 スパンのコンクリート橋の可能性について研究すること を試みたものである. 本橋梁の設計に先立って, その施 工上の問題点を検討する目的で, スパン $24 \mathrm{~m}$ の同形式 のコンクリートトラス橋である太田名部橋（1973 年完 成）を設計・施工し，その結果に基づいて，安家川橋梁 の設計および施工方法が決定された.

プレキャスト部材を用いたトラスの形式としてはワー レンおよびハウの両形式が考えられるが，ワーレントラ スは (1) プレキャスト部材を組立ててトラスとする場合 の部材接合部の 施工が 容易でないこと, (2) 斜材に引張 と圧縮の交番応力が生じるため, すべての斜材に PC 鋼 材を配置しなければならないが，このため PC 鋼材が格 点部に集中し, 格点部の $\mathrm{PC}$ 鋼材と鉄筋との配置が錯綜 して, 格点部が大きくなること, (3) 格点部の応力状態 が複雑になること, など設計・施工上の問題点が多いた め,ここでは現場における施工が比較的容易なハウトラ ス形式を用いることにした. またトラスとしては上路式 と下路式とが考えられるが, 施工上の問題点を少なくす ることを考えて上路式とし, 橋梁形式としては上路単純 ハウトラスとすることにした.

本瀮梁に対する検討は 1970 年から始められ，1971 年 にはトラス構造としての各種の実験が実施された. その 後 1972 年に下部工の設計・施工が行われ，1973 年に太 田名部橋の完成をみて上部構造の設計が完了した. 橋梁 全体の完成は 1975 年の 3 月である.

\section{3. 設計}

\section{(1) 概 要}

安家川橋梁は全長 $305.06 \mathrm{~m}$ で, 曲線半径 $700 \mathrm{~m}$, 勾 配 8\%。の間の中にあり,スパン $45 \mathrm{~m}$ (桁長 $45.9 \mathrm{~m}$ ) のトラス 6 連とスパン $27 \mathrm{~m}$ (析長 $27.9 \mathrm{~m}$ ) のトラス 1

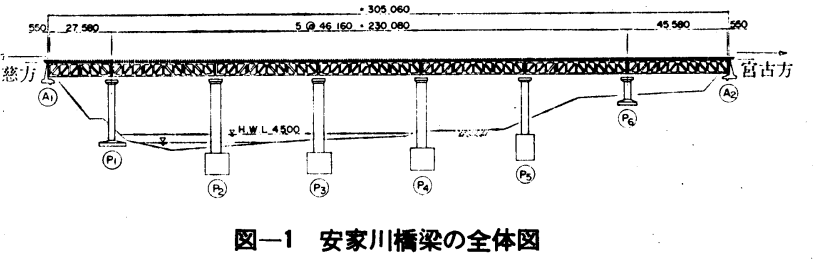

連より構成されている・トラス主構の高さは $5.45 \mathrm{~m}$ (全 高 $6 \mathrm{~m}$ ), パネル間隔は $4.5 \mathrm{~m}$ である.

本橋梁の構造上の特色は, トラス主構部材である上下 弦材・垂直材・斜材をすべて工場で製作されたプレキャ スト部材とし，コンクリートとしてはオートクレーブ養 生による超高強度コンクリート $\left(\sigma_{c k}=800 \mathrm{~kg} / \mathrm{cm}^{2}\right)$ を使 用して死荷重の軽減を計ったことである.このようなプ レキャスト部材の現場における組立作業を容易にするた め, 橋梁架設地点まで般入されたプレキャスト部材を平 面に置いてトラスの一部分を形成するような格子状の枠 組に組立て, これを引起こして, 架設地点に運搬・架設 してトラスの主構部材とするような新しい施工方法を開 発した. すなわち 1 連分のトラスは 2 組の 3 パネル分の 枠組と 1 組の 4 パネル分の枠組とから構成されている.

個々の枠組はプレキャスト部材を平面に八ウトラス状に 設置して, その部材間には場所打ち施工による目地コン クリート $\left(\sigma_{c k}=600 \mathrm{~kg} / \mathrm{cm}^{2}\right)$ を填充し, 鉛直材には PC 鋼棒によってプレストレストを導入して一体のものとす る. その枠組を引起こして支保工上に架設した後に, 枠 組間に目地コンクリート $\left(\sigma_{c k}=600 \mathrm{~kg} / \mathrm{cm}^{2}\right)$ を打設し, 3 分割された枠組の上下弦材に PC 鋼線を通してプレス トレスを導入し一体の構造にする.このように両側のト ラス主構が完成した後で, 上横桁・下横桁・耐震壁の施 工を行って，全体のトラス構造を完成させる.このよう な施工方法をとることを前提において, トラス部材の設 計を行った. トラス主粠の設計計算には表一2 に示す荷 重と表一3に示す許容応力度とを用いた. なお部材のコ ンクリートはオートクレーブ養生が行われているので, その乾燥収縮とクリープは小さいものと思われるが, プ レストレス量の増減量などを求める際には一般的な值で ある $\varepsilon_{s}=15 \times 10^{-5}$ および $\varphi=2.0$ を用いた.

この場合のよらに, プレキャスト部材を組立ててコン クリートトラスとすると, 横断面方向の㣚性をどのよう にして保持させるかが設計上の 1 つの問題点になってく る.ここではトラス両端と枠組の接合部の 4 箇所に場所 打ちコンクリートで耐震壁を設けて横断方向の㣚性を保 ち, トラス全体としての水平方向の剛性はトラス上面に 施工される床スラブで保持させる構造とした. すなわち 床スラブは全長 $46 \mathrm{~m}$ の連続した スラブとし， トラス の上横析に対して長手方向には伸縮でき, 水平方向には 


\section{表一2 設 計 荷 重}

\begin{tabular}{|c|c|c|c|c|}
\hline \multicolumn{4}{|c|}{ 活 荷 重 } & $\mathrm{KS}-16$ \\
\hline 衝 & 撃 & 係 & 数 & $\begin{array}{l}\text { 国鉄建造物設計標準による。ただし，トラス部 } \\
\text { 材については，各部材の影響線長を求めて，そ } \\
\text { の長さをスパンとするる值をとる. }\end{array}$ \\
\hline 群 & 集 & 荷 & 車 & $\begin{array}{l}500 \mathrm{~kg} / \mathrm{m}^{2}, \text { ただし, 主構に対しては KS 荷重と } \\
\text { 重好ない. }\end{array}$ \\
\hline 诰 & 心 & 荷 & 車 & $\begin{array}{l}\text { 曲線半栙 } 700 \mathrm{~m} \text { の区間内にあるので, 面上 } 1.8 \\
\mathrm{~m} \text { の位消に，水平に KS-16荷重の0.12 倍在作 } \\
\text { 用ざせる. }\end{array}$ \\
\hline 橫 & & 菏 & 車 & 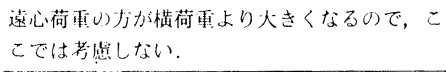 \\
\hline 風 & & it & T! & $\begin{array}{l}\text { 列車扯荷状態で風上側 } 150 \mathrm{~kg} / \mathrm{m}^{2} \text {, 風下側 } 100 \\
\mathrm{~kg} / \mathrm{m}^{2}\end{array}$ \\
\hline 雪 & & 苛 & 車 & $100 \mathrm{~kg} / \mathrm{m}^{2}$ \\
\hline 地 & 震 & 荷 & 重 & 水半霞度 0.2 , 垂直震度 0.1 \\
\hline 混 & 度 & 変 & 化 & 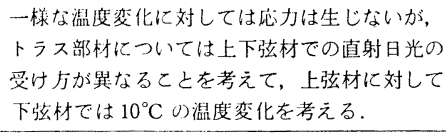 \\
\hline & & 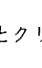 & & $\begin{array}{l}\text { 静定構造であるつで，構造系としては考慮しな } \\
\text { い. }\end{array}$ \\
\hline
\end{tabular}

拘束するような特殊な支承を介して支持されるようにし た. このトラスの水平方向の設計上の外力は主として地 震荷重であるが，地震荷重に対しては耐震壁でトラスの 横断面を保持し，床スラブでトラス全体としての水平曲 げモーメントに抵抗できるようになっている.

このように, 床スラブは水平荷重に対してはトラス主 構を支えて抵抗するが, 垂直荷重に対しては, その両者 は全く独立倠くものとした.すなわち, 床スラブとト ラス主構とは非合成構造として解析し, その間には支承 を入れる設計とした。これは設計およで施工を単純化す るためである。したがって床スラブはスパン $4.5 \mathrm{~m}$ の 10 スパン連続のスラブ であるとともに, 水平方 向にははり高さ $4.3 \mathrm{~m}$, スパン $45 \mathrm{~m}$ の単純ばり になっている.

\section{(2) トラス主構}

トラスの主構はプレキ ヤスト部材を結合して構 成されている. 現場での 継手部の施工を考える と、プレキャスト部材の 長さを長くすることが望 ましいが、プレキャスト 部材については (1) オー トクレーブ養生のための 高圧養生釜に収納できる こと, (2) 部材の 取扱が
表一3 使用材料と許容応力度

\begin{tabular}{|c|c|c|c|}
\hline \multicolumn{2}{|l|}{ 材 } & $\begin{array}{c}\text { 強度または材質 } \\
\left(\mathrm{kg} / \mathrm{cm}^{2}\right)\end{array}$ & $\begin{array}{c}\text { 許容応力度 } \\
\left(\mathrm{kg} / \mathrm{cm}^{2}\right)\end{array}$ \\
\hline \multirow{3}{*}{$\begin{array}{l}\text { コンクリ } \\
\text { ート }\end{array}$} & トラス主構 & $\sigma_{c k}=800$ & $\begin{array}{l}\text { 曲げ } \sigma_{b a}=270(350) \\
\text { 軸力 } \sigma_{c a}=230(300)\end{array}$ \\
\hline & トラス格点部 & $\sigma_{c k}=600$ & $\begin{array}{l}\text { 曲げ } \sigma_{b a}=200(260) \\
\text { 軸力 } \sigma_{c a}=170(220)\end{array}$ \\
\hline & $\begin{array}{l}\text { 横枌・酎震壁・ } \\
\text { 版 }\end{array}$ & $\sigma_{c k}=400$ & $\begin{array}{l}\text { 曲げ } \sigma_{b a}=140(180) \\
\text { 軸力 } \sigma_{c a}=110(145)\end{array}$ \\
\hline 筋 & $\begin{array}{lll}\phi 16 & \text { 以 } & \text { 上 } \\
z & \text { の } & \text { 他 }\end{array}$ & $\begin{array}{l}\text { SD } 35 \\
\text { SD } 30\end{array}$ & $\begin{array}{l}\sigma_{s a}=1800 \\
\sigma_{s a}=1600\end{array}$ \\
\hline PC 鋼材 & $\begin{array}{l}\text { OSPA } 100 \mathrm{~A} \\
\text { OSPA } 75 \mathrm{~A} \\
\phi 32 \\
\phi 26\end{array}$ & $\begin{array}{l}\text { SWPR } 1(24-\phi 7) \\
\text { SWPR } 1(18-\phi 7) \\
\text { SBPR } 95 / 110 \\
\text { SBPR } 95 / 110\end{array}$ & $\begin{array}{l}0.6 P_{u}=85.7 \mathrm{t} \\
0.6 P_{u}=64.3 \mathrm{t} \\
0.6 P_{u}=53.1 \mathrm{t} \\
0.6 P_{u}=35.0 \mathrm{t}\end{array}$ \\
\hline
\end{tabular}

注：（）は部材引張部または引張部材の許容压縮応力度

容易にできる重量および形状であること，(3) 長距離の 部材運搬打よび枠組構成後の引起こし・移動・架設作業 が容易なこと, などのことを考慮する必要があり，これ らからトラスを 3 分割する枠組の長さが決定され, 上下 弦材の長さが定められた. 最長の部材は, 中央部分の枠 組の上下弦材で，その長さは $17.7 \mathrm{~m}$ である. 垂直材・ 斜材て単一の部材として製作された。トラスを構成する ためのプレキャスト部材の接合方法については，表一4 のような種類について検討を行ったが, 現場での施工性 を考えて部材の製作誤差が吸収できる目地コンクリート 構造を用いることにした. この場合の継手コンクリート の長さは $55 \mathrm{~cm}$, 枠組の間の目地コンクリートの長さは $30 \mathrm{~cm}$ であるが，これらは主として鉄筋の接合およびコ ンクリートの施工性を考えて定めたものである.

このコンクリートトラスの部材断面力の算定にあたっ ては, 格点を剛とし, 各部材に軸力と曲げモーメントと
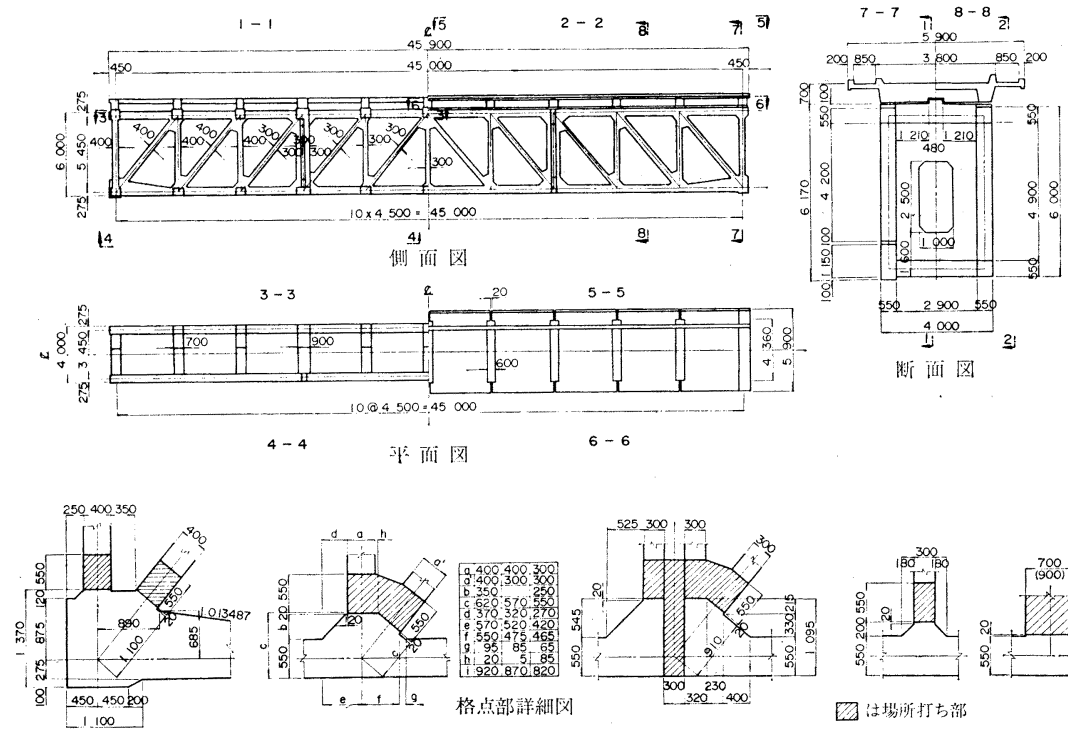

国蛙场打ち部

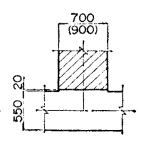

図一2 トラス主構の一般図 
表一4 プレキャスト部材の接合方法

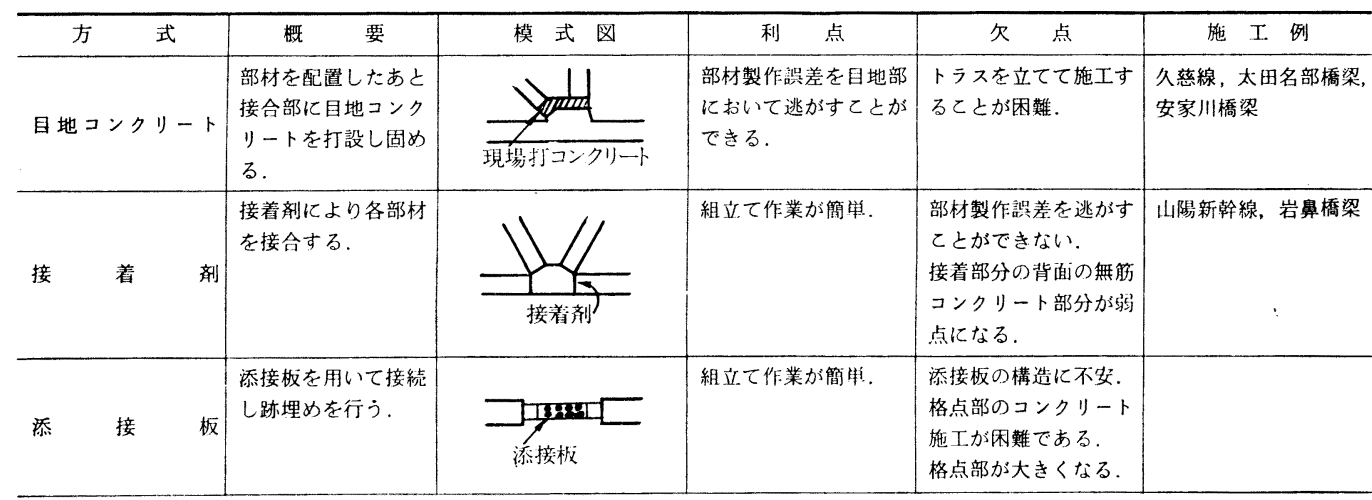

\begin{tabular}{|c|c|c|c|c|c|c|}
\hline 部 材 & $\begin{array}{l}\text { 軸力 } \\
N(\mathrm{t})\end{array}$ & $\begin{array}{c}\text { 曲げモー } \\
\text { ×ントM } \\
(\mathrm{t} ・ \mathrm{~m})\end{array}$ & $\begin{array}{c}\sigma_{N} \\
\left(\mathrm{~kg} / \mathrm{cm}^{2}\right)\end{array}$ & $\begin{array}{c}\sigma_{M} \\
\left(\mathrm{~kg} / \mathrm{cm}^{2}\right)\end{array}$ & $\begin{array}{c}\sigma_{N}+\sigma_{M} \\
\left(\mathrm{~kg} / \mathrm{cm}^{2}\right)\end{array}$ & $\begin{array}{c}\sigma_{N}-\sigma_{M} \\
\left(\mathrm{~kg} / \mathrm{cm}^{2}\right)\end{array}$ \\
\hline $5-6$ & 586.7 & 7.2 & 194.0 & 26.0 & 220.0 & 168.0 \\
\hline $16-17$ & 609.9 & 6.5 & 201.6 & 23.5 & 225.1 & 178.1 \\
\hline $2-12$ & 345.7 & 5.0 & 157.1 & 34.0 & 191.1 & 123.1 \\
\hline $2-13$ & 211.8 & 8.6 & 96.3 & 58.5 & 154.8 & 37.8 \\
\hline
\end{tabular}

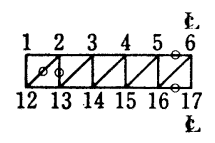

が作用するトラス構造として構造解析し設計を行った. これは一般の鋼トラスに比較して断面の剛性が大きいた めに，いわゆる二次応力が無視できなくなると考えたか らである. 構造解析は変形法によって行ったが, その結 果の一部を 表一5 に示す. 表一5 からわかるように, 本 橋梁の場合のトラス軸力に対するいわゆる二次応力は荷 重によって異なっているが, もっとも大きな断面力の作 用する部材で，上下弦材 $12 \sim 13 \%$, 斜材 $20 \%$, 垂直材 60\% である. コンクリート部材でトラスを構成する場 合には，部材に作用する曲げモーメント（二次応力）の 影響を無視することができないものと考えられる．部材 断面の寸法は PC 鋼材の配置から定まってくる部分もあ り，格点部の配筋はそこでのコンクリートの施工性を考 虑して定められた. トラス主構の有効プレストレス量は 上弦材で $20 \mathrm{~kg} / \mathrm{cm}^{2}$, 下弦材で $230 \mathrm{~kg} / \mathrm{cm}^{2}$, 垂直材で 24 $\sim 120 \mathrm{~kg} / \mathrm{cm}^{2}$ である.

\section{(3) 床スラブ}

床スラブについては, 前述のような垂淔荷重をうける スラブとしての働きとともに，地震荷重に対して全長 $45 \mathrm{~m}$ の水平ばりとして橋梁全体の水平剛性を保つ機能 をもっている.このような機能をもつ床版をトラス主構 完成後に施工するには, 従来の場所打ち施工による方法
が有利となる場合が多いが，これに対してプレキャスト スラブを使用することを検討してみた．これは床スラブ の施工が冬期の高所作業となることを考えたもので，こ のような場合には, (1) 現場でのコンクリートの施工管 理が容易になること, (2) 高所作業に対して, トラス本 体の架設に使用した施工機材が有効に利用でき, 工期の 短縮が可能になることなどプレキャストスラブを採用す ることによる利点が大きいので，ここではプレキャスト スラブとして設計を行った.

床スラブは $4.5 \mathrm{~m}$ のパネル間隔に合せたプレキャス トスラブ桁を地上で製作してから運搬し, トラス主構の 横桁間に架設し，その後に横桁上のプレキャストスラブ 間の目地コンクリートを打設して全長 $45 \mathrm{~m}$ の連続スラ ブとした. すなおち, 床スラブはスパン $4.5 \mathrm{~m}$ の 10 ス パン連続の スラブとしての 正負の曲げモーメント（+ $59.1 \mathrm{t} \cdot \mathrm{m},-54.4 \mathrm{t} \cdot \mathrm{m})$ に対して $16-\mathrm{D} 32$ が配笳され ている. スラブ桁の高さは $70 \mathrm{~cm}$ である. 目地コンク リート部分はプレキャストスラブから突出している鉄筋 を重ね合せて設計曲げモーメントに抵抗するように考え て設計を行ったが, $\phi 17.8 \mathrm{~mm}$ の PC 鋼より線 9 本を全 長にわたって配置してプレストレス $\left(10 \mathrm{~kg} / \mathrm{cm}^{2}\right)$ を導入 し, 目地部の補強を行っている. また床スラブはスパン $45 \mathrm{~m}$ の水平ばりとしての曲げモーメント $(921 \mathrm{t} \cdot \mathrm{m})$ に 対して, 両側に 36-D 32 の鉄筋を配㯰している. 目地 部ではこの両側の鉄筋を重ね合せ継手で接合している.

\section{（4）設計上の問題点の検討}

前節で示したコンクリートトラスは，いくつかのコン

\section{表一6 使用材 料}

\begin{tabular}{|c|c|c|c|}
\hline & $\begin{array}{l}\text { コンクリート量 } \\
\left(\mathrm{m}^{3}\right)\left(\mathrm{m}^{3} / \mathrm{m}\right)\end{array}$ & (t ) $\begin{array}{l}\text { PC 鋼材量 } \\
\left(\mathrm{kg} / \mathrm{m}^{3}\right)\end{array}$ & 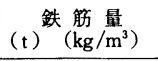 \\
\hline トラス主構 & $731(2.4)^{*}$ & $61.1(83.6)^{* *}$ & $99.9(136.7)^{* *}$ \\
\hline トラス全体 & $1061(3.5)$ & $66.2(62.4)$ & $200.6(189.1)$ \\
\hline 床 & $687(2.3)$ & $4.4(6.4)$ & $163.6(238.1)$ \\
\hline
\end{tabular}


クリート部材を接合して構成されているため, 格点での 断面形状はかなり複雑になっている．また，トラス枠組 をつくってから，その枠組を接合するような構造になっ ているため, 枠組の接合点での垂直材が 2 本になってい る.このように変った形状をしているので, 単一の線か ら構成されている格点を剛とするトラス構造としての解 析結果のみでは断面形状の適否が判断しにくいという問 題点があった. また，これまでにコンクリートトラスの 設計例がほとんどないということもあって，上述の設計 を確定する前に, 2 3 の実験的 および 解析的な研究を 行って, 設計方法について検討を行った. 以下, その研 究した成果の概要を示すことにする.

a) 有限要素法による解析

2 次元的な拡がりをもつ部材について, その応力分布 を求める手法としては有限要素法が広く用いられてい る. コンクリートトラスの格点部は (1) 応力が局部的に 集中していること, (2) コンクリートの引張強度が 小さ いこと，(3) 現場打ちコンクリートとプレキャスト部材 とでその材料特性が異なることなどのため, 格点部には ひびわれが発生しやすいものと考えられたので，まず有 限要素法によって格点部の忘力分布を求めてみた.

格点部はオートクレーブ 養生した 部材コンクリート $\left(\sigma_{c k}=800 \mathrm{~kg} / \mathrm{cm}^{2}\right)$ と接合目地コンクリート $\left(\sigma_{c k}=600\right.$ $\left.\mathrm{kg} / \mathrm{cm}^{2}\right)$ とから形成されているので，それぞれのコンク リートについて材料実験を行った。この結果, ヤング係 数についてはほとんど差が認められなかったのでヤング 係数 $\left(E_{c}\right)$ をいずれも $400000 \mathrm{~kg} / \mathrm{cm}^{2}$ とし, ポアソン

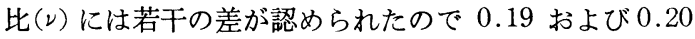
として計算を行った. 計算した格点はトラス端支点部, トラスの枠組の接合部, トラス枠組の中央部の 3 箇所で, 外力としては設計荷重による軸力とプレストレスカとを 加えた. 図一3 は解析結果の一例として, 形状の複雑な トラス枠組の接合部の応力分布を示したものである. 図

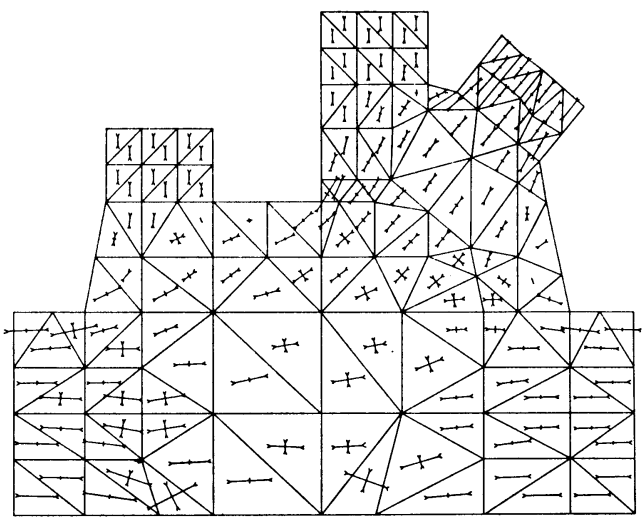

荷雨=プレストレスカ十死荷重十活荷重半械 LOADING NO.2 $1031 / \mathrm{cm}^{2}$ 図一3 有限要案法による解析結果

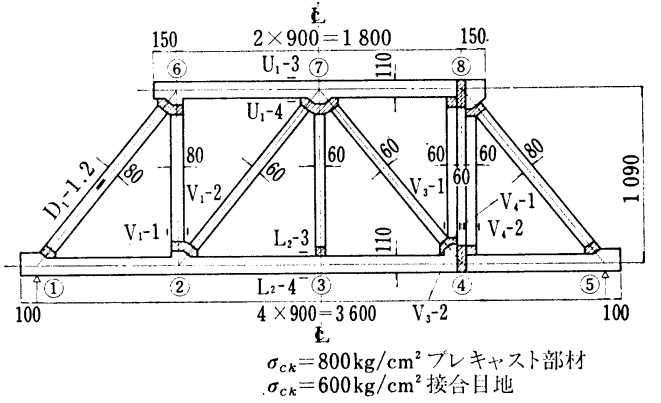

図一4 コンクリート模型トラスの一般図

一3のような複雑な格点においても, そこに大きな引張 忘力は発生しない.これはプレストレスの作用によるも ので，その他の計算例もほぼ同じような傾向を示してい る. これらの結果よりトラス部材の格点には著しい引張 応力は発生しないものと判断した.

b）コンクリートトラスの模型実験

実際のコンクリートトラスに対して, 格点を剛とする 力学的なトラスとしての解析結果がどの程度の適合性を もつものかを見るために, 1/5 のコンクリートトラスの 縮尺模型をつくって，これに外力を加えて変形と部材応 力とを測定し，理論値との対応を考察してみた. 図一4 はこの模型の一般図で, 実体のトラスと同じように弦材 を先に製作し，その間に接合目地コンクリートを打設し プレストレスを導入して 2 つの枠組を作り, 格点 (4),8 でそれを接合してトラスとしたものである. 模型トラス は 2 体製作し, その 1 つは静荷重を載荷して試験し, 他 の 1 つは繰り返し荷重を載荷してトラスの疲労耐力を試 験した. 静荷重試験では荷重を上弦材の格点 (6), (7), 8) のそれぞれに加えて, そのときのトラスの変形と応力を 測定した. 応力測定位置は各部材の格点部の接合点およ び部材の中央部付近の両側で，そこにワイヤーストレン ゲージ（ゲージ総数 56 点）を貼って測定した. 図一5, 6 は測定結果の一例として, トラスのたわみと図一4に示 す位置の部材のひずみの実測值を示したもので, 破線は 実測值, 実線は格点を剛と考えたトラスの計算值であ る.これらの結果より判断すれば, 格点を剛とするトラ スとしての計算值は実測值によく一致しており，この計 算結果に基づいて設計を行ってよいものと考えられる.

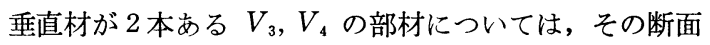

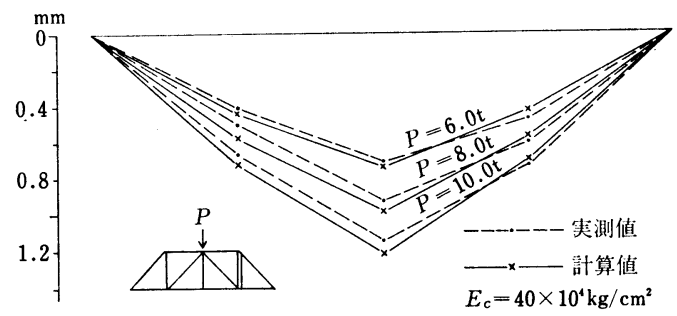

図一5 静荷重载荷時のたわみ 


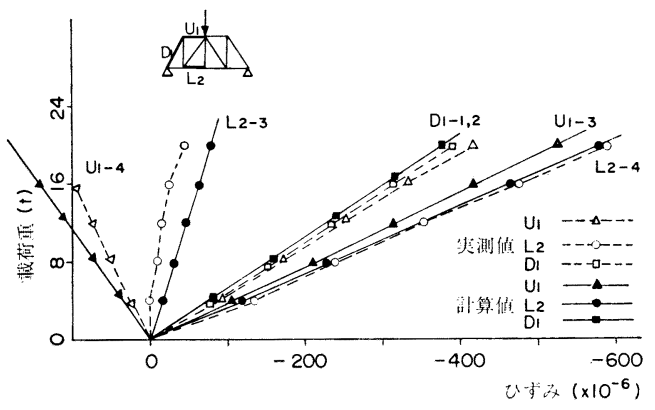

(a) $U_{1}, L_{2}, D_{1}$

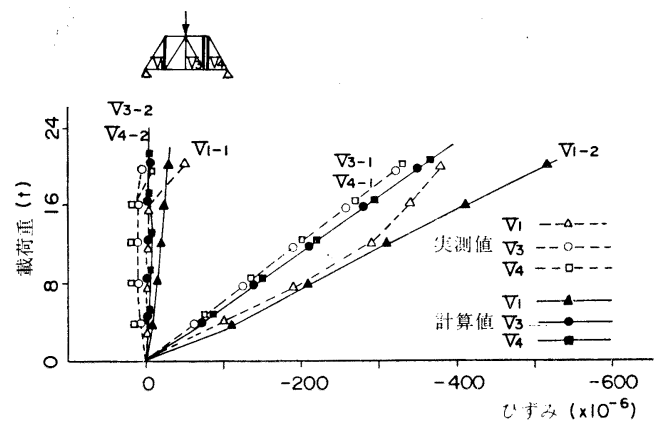

(b) $\nabla_{1}, \nabla_{3}, \nabla_{4}$

図一6 コンクリート模型トラスの実験結果（ひずみ） ( $L_{2-3}, L_{2-4}$ 等については図一4 参照)

および断面剛性を，おのおのの垂直材の断面および断面 剛性の 2 倍の值にとって計算を行ったものであるが，実 験結果はこの仮定を肯定している.この模型トラスは, 静荷重載荷による実験の後で, 荷重を格点 (7) に加えて 破壊状態をみることにした．荷重 $13.6 \mathrm{t}$ 前後で垂直材 $V_{1}$ の下端の目地コンクリートの打継目付近にひびわれ が発生したが，コンクリートの引張強度を零とした場合 のひびわれ 荷重の理論值は $13.4 \mathrm{t}$ である. その後, 荷 重の増加とともにひびわれの大きさが増大し, PC 鋼材 のねじ部が破断する危険が生じたので, 荷重 $41.5 \mathrm{t}$ で 載荷を中断した.このときの垂直材 $V_{1}$ の格点 (2)-(6) 間 を PC 鋼棒断面 (SBPR 95/110 $\phi 13 \times 1), V_{3}, V_{4}$ の下端 格点 (4)をヒンジ構造とすると, 格点 (2)-(6) 間に作用す る軸力の理論值は $17.2 \mathrm{t}$ となるので, $\mathrm{PC}$ 鋼棒の引張強 度 $14.6 \mathrm{t}$ に近い軸力が作用していたものと考えられる。 荷重を再び元の状態にもどしたときには，生じたひびわ れは閉合し, 各部材ともほとんど異常が残らなかった。 この模型トラスは実際のトラスとほとんど同じような考 え方で設計されているので, 実際のトラスの破壊限界状 態も垂直材の $\mathrm{PC}$ 鋼棒の破断によって起こるものと考え てよい. 疲労試験用の模型トラスは格点 (7) $2 \sim 20 \mathrm{t}$ の荷重を繰り返し載荷し, 垂直材のひびわれ荷重を越え て荷重を振幅させた. 105 万回の繰り返しを行ったが, 垂直材にもまたその他の部材にも疲労の影響は見られな かった.そこで静的に荷重を加えて, 静載荷試験と同じ

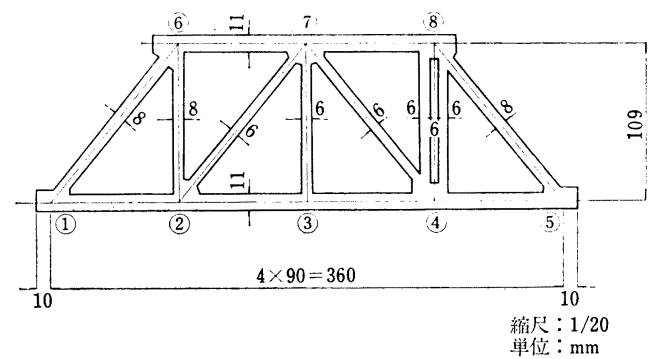

図一7光弾性実験用のエポキシモデル

ように荷重と変形および応力との関係を求めてみたが, この結果は静載荷試験での結果とほとんど一致した。ま たその後に破壊試験を行ったが, $40 \mathrm{t}$ まで荷重を加えて も垂直材のひびわれの大きさが成長するのみでほかには ほとんど変化がみられなかった．これらの結果よりこの 形式のトラスは 100 万回程度の荷重の繰り返しに対して 十分の耐力を有しており, 疲労の影響を考慮しなくてよ いものと判断した.

c) 光弾性実験

前述の模型トラスの研究結果を別の角度から検討する ため, 厭さ $9 \mathrm{~mm}$ のエポキシ材を用いて 図一7 に示す ような光弾性モデルを製作し，これに PC 鋼材によるプ レストレスの導入時の状態および上弦材の格点 (6), (7), (8)に外力を加えた状態での 縞次数を求め, これから部 材応力を計算してみた. 光弾性実験の結果の一例を示す

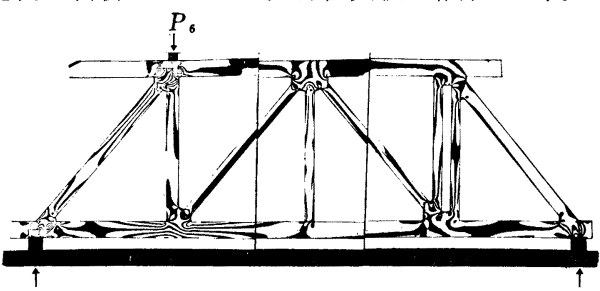

（a）載荷位置：格載 (6

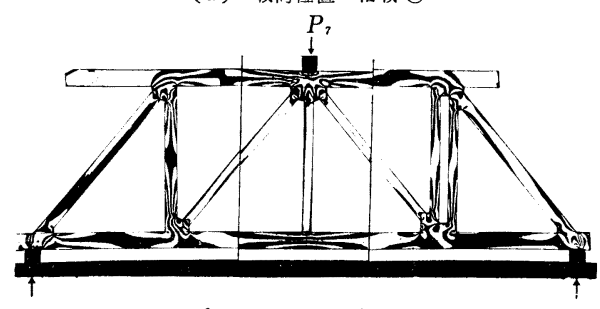

（b）点荷位置：格点 (7)

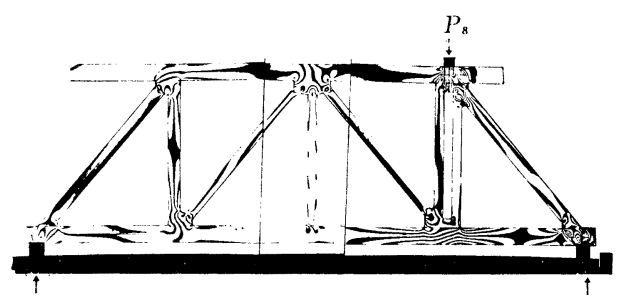

（c）載荷位置：格点 (8)

写真一2 光弾性実験の結果 
と 写真一2 のようになる.この結果も 理論解析の結果 と傾向的には一致しており, 垂直材の応力がトラスの耐 力を支配するものであることを示している．また，この 光弾性実験より,ひびわれ応力 $\sigma_{t}=50 \mathrm{~kg} / \mathrm{cm}^{2}$ として求 めたひびわれ荷重は約 10〜12 t で，コンクリート模型 トラスによる実験結果とほぼ一致している.

このエポキシモデルによる光弾性実験とは別に, 全体 で 10 パネルのトラス模型およびトラス枠組の接合部で 垂直材が 2 本になる部分の部分模型についても, エポキ シモデルをつくって光弾性実験を行って検討を行った. この結果によれば，垂直材が 2 本ある部分のせん断応力 は平均せん断応力の 1.5 2.0 倍になっているが，これ はプレストレスで十分に打ち消すことができる大きさの ものであり, 垂直材と上下弦材との取付部分の応力集中 も他の部分の值より 2 割程度大きくなる位で, 設計上大 きな問題とならないことが明らかとなった.

\section{4. 太田名部橋梁における載荷試験・振動試験}

\section{（1） 橋梁の概要}

太出名部橋梁は, 安家川橋梁と问じ久綕線建設工事に おいて, 久慈起点 $25.491 \mathrm{~km}$ の地点に作られた スパン $24 \mathrm{~m}$, トラス主構の高さ $2.65 \mathrm{~m}$, 全高 $3.05 \mathrm{~m}$, パネル 間隔 $2.4 \mathrm{~m}$ の架道橋で, 安家川橋梁の 設計・施工方法 を研究的に確認する意味で, 同一の設計・施工方法を用 いて建設された橋梁である.この橋梁の設計荷重, 使用 材料, 設計計算の方法, 材料の許容応力度などはまった く前章に示した内容と同一である.

トラス主構は, 安家川橋梁と同じ条件でオートクレー ブ養生して製作されたプレキャストコンクリート部材を 現地に運搬して架設したものであるが, 部材寸法が小さ いため（最大長さ $9.4 \mathrm{~m}$, 最大重量 $5 \mathrm{t}$ ), オートクレー ブ養生での養生温度サイクルは昇温 12 時間, $180^{\circ} \mathrm{C}$ 保 持の定常時間を 8 時閒, 降温 19 時間と安家川橋梁の場 合より若干短くなっている. 現場での架設は橋梁後方の 盛上上にトラス部材を取卸し，トラス枠組を構成し た後で引起こし，上下弦材にプレストレスを導入し て一体のトラス主構としてから支保工上を引き出し て，所定位置に架設したもので，トラス主構の架設 後に横桁・耐震壁・床版のコンクリート施工を行っ て橋梁を完成したが，この施工方法は後で述べる安 家川橋梁での施工方法と同じである.ただし床版コ ンクリートは安家川橋梁ではプレキャストコンクリ ートを用いたが，ここではトラス主構の架設後にそ の上に型枠を組立てて，現場打ちコンクリートによ ってて施工した.この橋梁の使用材料は，プレキャス
トコンクリート $31 \mathrm{~m}^{3}$, 現場打ちコンクリート $56 \mathrm{~m}^{3}$, $\mathrm{PC}$ 鋼材 $4.9 \mathrm{t}$, 鉄筋 $11 \mathrm{t}$ （主構 $6.1 \mathrm{t}$, 床版 $5.3 \mathrm{t}$ ) で ある・

\section{（2）載 荷 試 験}

太田名部橋梁は安家川橋梁の設計・施工方法を検討す るといら目的で作られたものであるので, 設計方法を確 認するため, 橋梁の完成後に静荷重を加えて載荷試験を 行った. 載荷試験用の荷重としては, コンクリートブロ ック $(1.2 \times 1.2 \times 0.9 \mathrm{~m}, 2.94 \mathrm{t})$ を 30 個作り これを クレーンで橋梁上に積み上げた. 載荷状態は (1) スパン 中央にコンクリートブロック 30 個を全幅に載荷した場 合, (2) スパン $1 / 4$ 点にコンクリートブロック 30 個を 全幅に載荷した場合, (3) スパン中央にコンクリートブ ロック 15 個を片側に載荷した場合, の 3 通りである. 以下, 載荷試験における測定結果の概要について示すこ とにする.

a)たわみ測定

トラス下弦材の各格点 11 箇所のたわみをダイヤルゲ ージによって測定した. 図一8 はその測定結果を示した ものである.この図の中の計算值は、コンクリートのヤ ング係数を供試体による実測值 $3.76 \times 10^{5} \mathrm{~kg} / \mathrm{cm}^{2}$ を用 いて求めたもりである. 実測值は計算值をやや下回って いるが, 現場測定としては比較的よく一致している. 実 測值が小さくでたのは, 支承部のすべりが若干拘束され ているためではないかと考えている。

b）部材の応力測定

トラス部材の主要点 60 箇所にワイヤーストレンゲー ジを貼りつけ，また 5 箇所にカールソンひずみ計を設置 して部材応力の測定を行った. 部材応力の測定結果は, 現場測定としては計算值に比較的よく一致している. 中 央載荷時の最大応力は上下弦材に生ずるが，そのときの 計算值 $-26 \mathrm{~kg} / \mathrm{cm}^{2},+54 \mathrm{~kg} / \mathrm{cm}^{2}$ に対して, 部材のヤ ング係数を $3.76 \times 10^{5} \mathrm{~kg} / \mathrm{cm}^{2}$ として換算した実測応力 は $-34 \mathrm{~kg} / \mathrm{cm}^{2},+48 \mathrm{~kg} / \mathrm{cm}^{2}$ である. 同じ荷重状態で のカールソンひずみ計での測定結果もワイヤーストレン
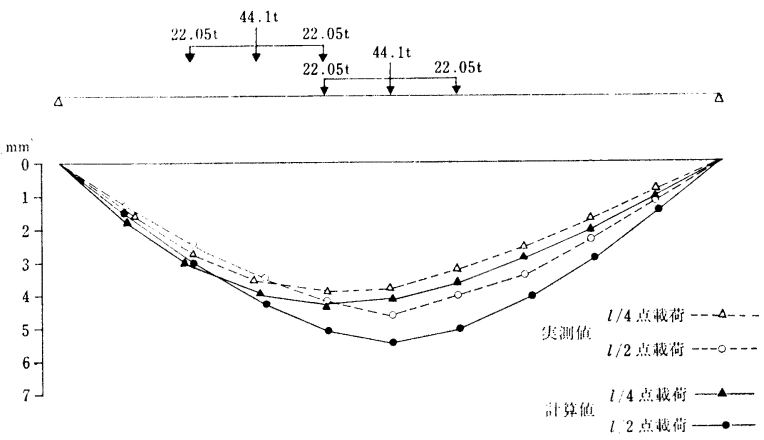

図一8 太田名部橋梁のたわみの測定結果 
ゲージによる値とよく一致している.

c）ひびわれ測定

荷重載荷とともに微細なひびわれが上下弦材に数箇所 発生したので, これをまたいでコンタクトゲージを貼っ て，そのひびわれの成長を測定した．またプレキャスト 部材と接合目地コンクリートとの接合部をまたいでコン タクトグージを貼って，そこの部分の測定も行った．全 荷重載荷時における上下弦材のひびわれ幅は $3.8 \times 10^{-3}$, $2.9 \times 10^{-3}, 1.4 \times 10^{-3} \mathrm{~mm}$ ，部材接合部での值は $4.9 \times$ $10^{-3}, 2.6 \times 10^{-3}, 2.3 \times 10^{-3}, 1.7 \times 10^{-3} \mathrm{~mm}$, で $1 / 4$ 点 載荷の状態ではそれぞれ $5.6 \times 10^{-3}, 2.9 \times 10^{-3}, 2.5 \times$ $10^{-3}, 1.9 \times 10^{-3}, 1.7 \times 10^{-3}, 0.7 \times 10^{-3}, 0.7 \times 10^{-3} \mathrm{~mm}$ で部材の耐力に対しては特に問題のない值であった.

\section{（3）振動 試験}

静荷重による載荷試験の後で, 橋梁上に $15 \mathrm{t}$ 起振機 を据付けて，0 8 Hz の範囲で鉛直方向，水平方向（橋 軸直角）に加振して, 振動試験を行ったが, 実際の橋梁 にはこの後で道床バラストが施工されるので, その重量 と列車重量とを考えて, 静荷重試験用のコンクリートブ ロック 30 個を等間隔に橋梁上に載荷した状態で加振し た.この振動試験では, 上弦材, 下弦材, 床版の位置で の中央から片側 3 パネル区間の動的ひずみ・動的変位・ 振動加速度を測定した。

鉛直方向加振時の 動的変位と振動加速度の測定結果 は，どの測点での值もよく似た傾向を示している. 図一 9 (a) はその結果の一例を示したもので, 中央の下弦材 の動的変位について, 起振力を $1000 \mathrm{~kg}$ に換算した場
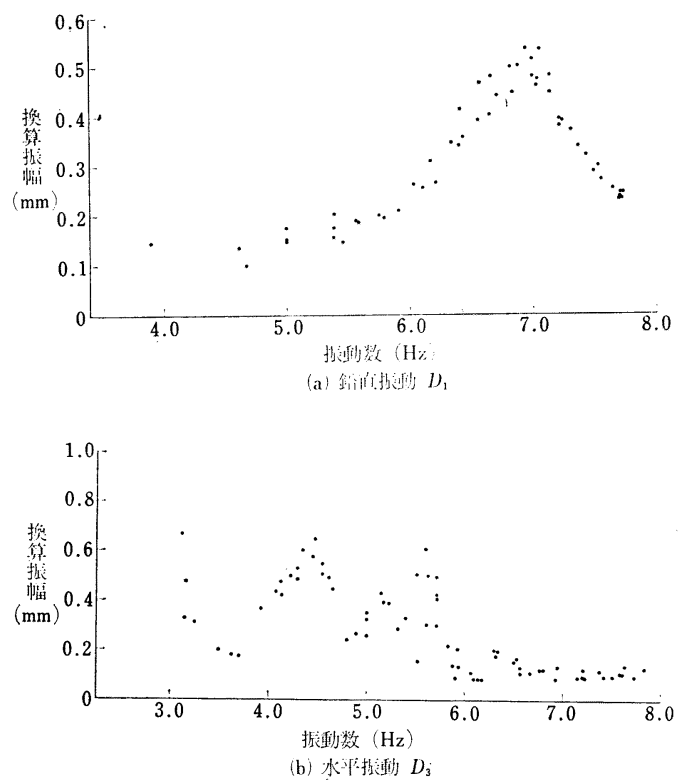

図一9 太田名部橋梁の振動試験結果
合の応答曲線である.これより曲げ振動の 1 次固有周期 は $7.0 \mathrm{~Hz}$ ，減衰定数は $5 \%$ であることがわかる.トラ ス主構のみの 固有周期の計算值は $6.05 \mathrm{~Hz}$, 床版がトラ ス主構と一体となっているとした場合の固有周期は $8.95 \mathrm{~Hz}$ である.この橋梁の床版はトラスの横桁の上に $2500 \times 150 \times 10 \mathrm{~mm}$ のネオプレーン板を介して支えら れているので, このネオプレーン板の弾性的な結合を考 慮して固有周期を求めると $6.6 \mathrm{~Hz}$ となり実測值に近い 結果となっている.このことよりネオプレーン板を介し て, トラスと床版とが一体となって振動しているものと 考えられる。

水平方向に加振した場合の測定結果は, 垂直方向に加 振した場合よりも結果はやや複雑で複数のモードが存在 していることを示しており, 測定された固有周期として は $2.9 \mathrm{~Hz}, 4.5 \mathrm{~Hz}, 5.8 \mathrm{~Hz}$ あたりにピークが認められ た. 図一9 (b) はスパン中央の下弦材の水平変位につい て, 起振力 $1000 \mathrm{~kg}$ に換算した場合の応答曲線である. 鉛直振動の場合と同じようなトラスと床版とを一体と考 えた振動モデルによる計算結果によれば，ねじり振動の 1 次が $3.0 \mathrm{~Hz}$, 曲げ振動の 1 次が $4.9 \mathrm{~Hz}$ である. 実験 では, $5.8 \mathrm{~Hz}$ 加振時においても，トラスは $2.9 \mathrm{~Hz}$ の 态答をしており, 中央加振といらことのため 2 次の 5.8 $\mathrm{Hz}$ においても 1 次モードが卓越したものと思われる. 以上振動試験の結果について示したが，振動周期はいず れも高く, 線形性を保って挙動しており, 橋梁として特 に問題となることはないものと考えられた.

\section{5. プレキャストコンクリート部材の製作}

\section{(1) 概 要}

プレキャストコンクリートのトラス部材は日本コンク リート工業 (株) 川島工場の専用の部材製作ヤードで製 作され，安家川の架設現場まで運搬された.

製作ヤード内で取扱う部材は最大重量 $15 \mathrm{t}$, 長さ 18 $\mathrm{m}$ であるのでその長大部材の製作精度をあげること, 部 材の打込みおよび取扱いの際に重機が接近することなど

表一7 主 要 材 料

\begin{tabular}{|c|c|c|c|c|c|c|}
\hline \multirow{2}{*}{ 材 } & \multirow{2}{*}{\multicolumn{2}{|c|}{ 料 }} & \multirow{2}{*}{ 種 } & \multicolumn{3}{|c|}{ 性 } \\
\hline & & & & 比重 & F.M & 吸水量 \\
\hline & $x=$ & & 普通ポルトランド & 3.17 & - & - \\
\hline & 骨 & & 茨城県铎行川産 & 2.63 & 2.59 & 1.70 \\
\hline 粗 & 骨 & & 荻城県岩瀬産砕石 & 2.60 & 6.86 & 1.20 \\
\hline 混 & 和 & 材 & 減 水 剂* & 1.21 & - & - \\
\hline 鉄 & & 筋 & $\mathrm{SD} 35, \mathrm{D} 16, \mathrm{D} 22$ & (主筋), & $30 \phi 9$ & 鉄筋) \\
\hline $\mathrm{PC}$ & $C$ 鋼 & 材 & 仮緊張用 PC鋼線 & $\phi 9$ & 鋼棒 $\phi 2$ & $\phi 27$ \\
\hline
\end{tabular}


表一8 コンクリートの配合

\begin{tabular}{|c|c|c|c|c|c|c|c|c|c|}
\hline $\begin{array}{c}\begin{array}{c}\text { 粗骨材最大寸法 } \\
(\mathrm{mm})\end{array} \\
\end{array}$ & $\begin{array}{c}\text { スランプの範囲 } \\
(\mathrm{cm})\end{array}$ & 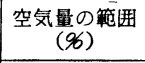 & $\begin{array}{c}\text { 水セxント比 } \\
(\mathscr{C})\end{array}$ & $\begin{array}{c}\text { 細骨材率 } \\
(\%)\end{array}$ & $\begin{array}{c}\text { 水 } \\
(\mathrm{kg})\end{array}$ & $\begin{array}{c}\text { セxント } \\
(\mathrm{kg})\end{array}$ & $\begin{array}{c}\text { 細 骨 材 } \\
(\mathrm{kg})\end{array}$ & $\begin{array}{c}\text { 粗 骨 材 } \\
(\mathrm{kg})\end{array}$ & $\begin{array}{c}\text { 混 和 郕 } \\
(\mathrm{kg})\end{array}$ \\
\hline 20 & $12 \pm 2.5$ & - & 30 & 39.5 & 159 & 530 & 677 & 1035 & 7.95 \\
\hline
\end{tabular}

のことを考慮して型枠周辺に厚さ $20 \mathrm{~cm}$ の基礎コ ンクリートを打設した。なお製作ヤードには $35 \mathrm{t}$ 吊りクローラクレーンを常駐させて資材や部材の移 動に使用した。

\section{（2）コンクリートの配合}

トラス部材の製造に使用した主要材料とコンクリ 一トの配合は,オートクレーブ養生を行らことを前 提として 表一7,8 のように定めた. オートクレー ブ養生によって高強度コンクリートが得られるの は, 高温高圧蒸気中における水熱反応によって結晶する トベルモライトによるものとされており，この結晶の生 成にはシリカが必要であるので, 細粗骨材にはシリカ質 を多く含む骨材を用いた。

コンクリートの配合は設計基淮強度 $800 \mathrm{~kg} / \mathrm{cm}^{2}$ に対 して定めたものであるが，プレキャスト部材の厚さが最 大 $55 \mathrm{~cm}$ で，オートクレーブ 養生する部材としては相 当厚く,またこのような超高強度コンクリートを上部構 造物に使用した例もなかったので, 強度の割増係数を 1.1 として配合設計を行った。コンクリートには高性能 減水剤（ポリアルキルアリルスルフォン酸ナトリウム 塩）を使用することにしたが，この減水剤は使用量によ って材料分離が起こったり，また経過時間に伴らスラン プドロップが大きいといった性質をもっている．また非 常に粘性に富んでいて, スランプ $8 \mathrm{~cm}$ 以下では取扱い が困難になる場合もあり，逆に $18 \mathrm{~cm}$ 以上になると安 定したコンクリートを得ることが難しいという材料であ るので，作業性が良く安定したコンクリートが得られる ように考えて，スランプを $12 \pm 2.5 \mathrm{~cm}$ とした. コンク リート作業は 2 月の厳冬期から 7 月の酷暑期にわたった ので，冬期には蒸気を用いて水および骨材を温めること によってコンクリートの練上り温度を $18^{\circ} \mathrm{C}$ 前後に保 ち，スランプドロップの激しい夏期には強度に悪影響を 与えない範囲で減水剤の使用量を調節し，また打込み完

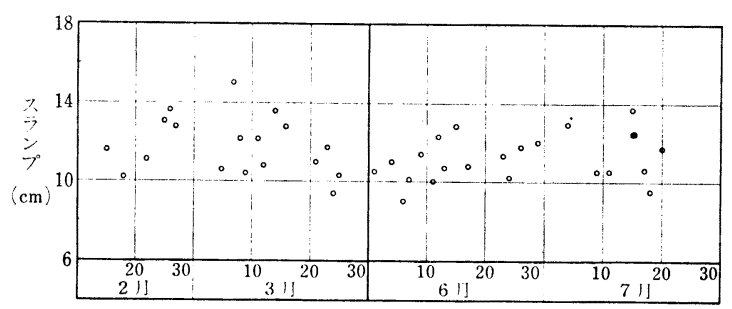

図一10 冬期およひ夏期におけるスランプの測定結果

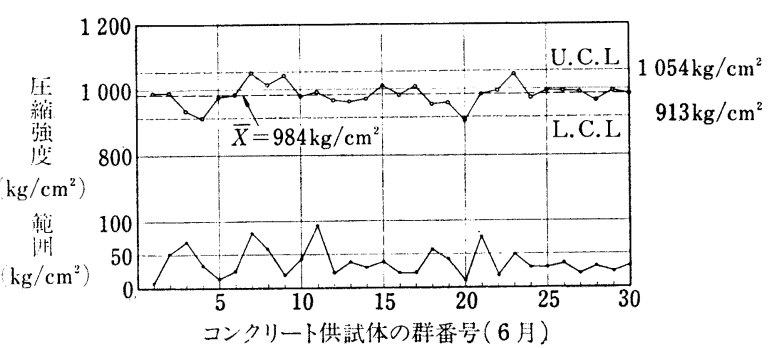

図一11 オートクレーブ養生後の压縮強度

了までの時間をできるだけ短縮するように努力した．冬 期の最低気温は $-5^{\circ} \mathrm{C}$ 前後であり, 夏期の屋外の温度 は $30 \sim 35^{\circ} \mathrm{C}$ であったが, 前述のように管理したコンク リートの 2〜3 月および 6 7 月におけるスランプは図 -10 に示すように大差なく, 部材製造期間を通じて 12 $\pm 2.5 \mathrm{~cm}$ の範囲をほぼ満足しており, 平均して $11 \mathrm{~cm}$ 程度であった。

コンクリートは上述の配合に基づいて入念に施工され たので，圧縮強度のばらつきを小さくすることができ た. 図一11 はオートクレーブ養生後の圧縮強度の管理 図の一例で，工事期間中もほぼ同様な推移をたどってい た.オートクレーブ養生後のコンクリートの平均圧縮強 度は $984 \mathrm{~kg} / \mathrm{cm}^{2}$, 標準偏差は $44.0 \mathrm{~kg} / \mathrm{cm}^{2}$, 変動係数は $4.5 \%$ である. なおスランプと圧縮強度の間には明確な 相関関係は認められなかった。

\section{（3）オートクレーブ養生}

コンクリートの養生は 2 段階に分けて行った. 第 1 段 階は通常の蒸気養生であり, 第 2 段階はオートクレーブ 養生である. 蒸気養生は脱型強度の早期確保と, 型枠回 転率の向上およびオートクレーブ養生を効果的に行うた めのもので, コンクリートの打込み終了後最低 4 時間の 前置き時間をとったあと, 最高 $65^{\circ} \mathrm{C}, 12$ 時間を原則と する養生を行った. 養生は屋外でシートをかけて行った が, 脱型時強度が $300 \mathrm{~kg} / \mathrm{cm}^{2}$ 以上であることを条件 としたため, 冬期の養生時間は 13〜14 時間となり, 夏期には 9 10 時間であった.

オートクレーブ養生は, $180^{\circ} \mathrm{C}, 10$ 気圧の高温高圧 蒸気による養生である.オートクレーブ養生による超 高強度コンクリートを用いた製品として PC パイル があるが, その肉厚は $10 \mathrm{~cm}$ 程度であって, 今回の トラス部材のようなマッシブなコンクリートに関する 


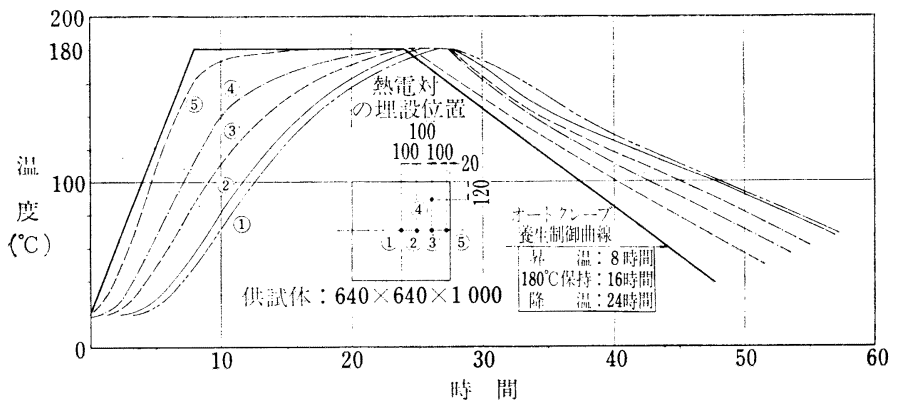

図一12 オートクレーブ養生によるコンクリート 内部の温度曲線の例

オートクレーブ養生の技術はまだ確立されていない。そ こでトラス部材とほぼ同一断面の 大型の供試体をつく り，この中に熱電対を埋設してオートクレーブ養生を行 い, 熱電導の状態, コンクリート内部の温度分布, コン クリート表面のひびわれの状態などを調査した. 実験結 果の一例は図一12 に示すようであって, これはオート クレーブ養生の時間のサイクルを昇温 8 時間, $180^{\circ} \mathrm{C}$ 保 持 16 時間, 降温 24 時間とした場合のものである.この 図からオートクレーブ養生開始後 10 時間後におけるコ ンクリートの 表面部と中心部の 温度差は $100^{\circ} \mathrm{C}$ 程度あ ること, 中心部の養生時間が不足していることなどのこ とを指摘することができて, この養生時間サイクルは適 当でないことがわかる. 蒸気養生ののち昇温 3 時間, $180^{\circ} \mathrm{C}, 10$ 気圧に保持 3 時間, 降温約 10 時間のオート クレーブ養生を行った場合には, 供試体にプレストレス を導入してないものには有害なひびわれが発生し, 最大 $0.25 \mathrm{~mm}$ のひびわれが生じた. しかし, 仮プレストレ スを導入したものでは有害なひびわれは発生していな い.このような一連の実験によって，養生時間を長くす れば断面中心部まで十分に養生できることが確認され た.また有害な熱応力が生じないよらな温度の上昇率お よび下降率と, 表面ひびわれを最小にする養生時間サイ クルおよび配合などを定めることができた.これより,厚 さ $55 \mathrm{~cm}$ のコンクリート部材の場合に適する養生時間 サイクルとして, 昇温 15 時間 (温度上昇率 $10^{\circ} \mathrm{C} /$ 時), $180^{\circ} \mathrm{C}$ 保持の定常状態を 20 時間, 降温 20 時間（温度

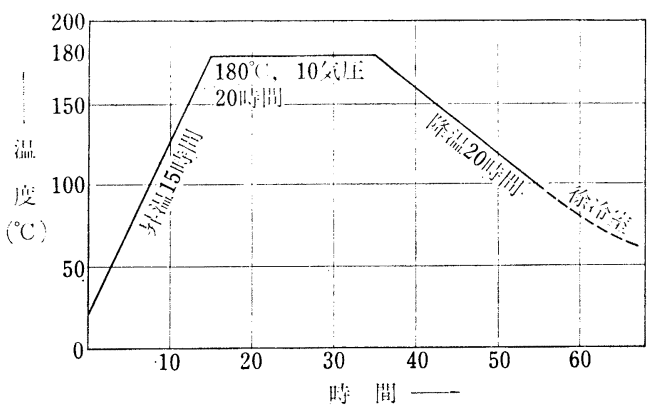

図一13 オートクレーブ養生の温度と時間
下降率 $4^{\circ} \mathrm{C} /$ 時）が定められた. 養生後 はさらに徐冷室を使用して, 外気温度ま で徐々に冷却させることにした（図一 13).

またここで養生される部材はかなり マッシブなものであるので, その断面内 に所期の強度が均一に得られているかど うかは明らかでない。このことを確かめ るため, $40 \times 40 \times 40 \mathrm{~cm}$ のコンクリート 供試体をオートクレーブ養生して，この 表面近くと中心部とから $10 \times 10 \times 10 \mathrm{~cm}$ の立方体の 供試体 18 個を切り出して強度試験を行っ た. オートクレーブ養生の条件は昇温 12 時間, 保持 8 時間, 降温 19 時閒である.この結果は, 中心部の平均 強度 $983 \mathrm{~kg} / \mathrm{cm}^{2}$ に刘して, 周辺部の平均強度は 1030 $\mathrm{kg} / \mathrm{cm}^{2}$ となっており, 場所による差は大きいものでな いことがわかった.

オートクレーブ 養生用の㙼釜は内径 $3.0 \mathrm{~m}$, 坟さ $31 \mathrm{~m}$ である.上下弦材の格点部は斜材, 吿直材, 横桁 方向の接続用鉄筋が突出しているので，大星の部材をオ 一トクレーブ釜内に収納することは困難であった。この ために, 合計 384 本のプレキャスト部材を 47 [に分 けてオートクレーブ養生を行うことになった.

当初, オートクレーブ養生によってコンクリート表面 にひびわれが発生することが䀣念されたが，後述するよ らな仮プレストレスを導入したこと，ひびわれの発生が 予想される部分を鉄筋で補強したこと, オートクレーブ 養生の時間を長くし, 温度の昇降の勾配を相当緩やかに したことなどの対策を立てたことによって，有害なひび われはまったく発生せず, 微細なひびわれがわずかに発 生した程度であった。 垂直材および斜材は そのコンクリート厚 さが $30 \sim 40 \mathrm{~cm}$ 程 度で, 上下弦材に比 較して寸法が小さか ったので,ひびわれ の発生はまったく認 められなかった. 写 真一3 は接合鉄筋の

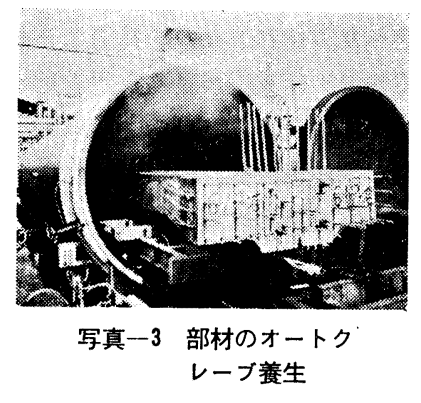

多い下弦材をオートクレーブ釜に挿入する状態を示した ものである.

\section{（4）配筋およびコンクリートの施エ}

鉄筋はあらかじめかご状に組立てたものを型枠内に配 置し, これに各点部における鉛直材, 斜材, 横桁方向の 接続鉄笳および PC 鋼材定着部の補強筋を取付けた. 格 
点部および PC 鋼材定着部付近では, 部材方向の接合鉄 筋とシースおよび補強筋とが錯綜しており，部材の製造 作業中に問題が生ずることも考えられたので, 実物部材 の製作実験によってこれらの点を検討した．この実験で は, 配筋の適否および組立順序, コンクリートの打込 み・締固め・仕上げ方法, 脱型の作業方法などを検討し たもので,これらの結果を参考にして部材製作の詳細が 定められた.

型枠は鋼製のものを使用し，工事期間中を通して底型 枠の水平調整を行って精度の維持につとめた.

超高強度用の粘性の大きいコンクリートの打込みに際 して, その練混ぜ効果をあげるために, $1 \mathrm{~m}^{3}$ の強制擋 拌式のミキサを使用し，1 1バッの練上り量を約 0.6 $\mathrm{m}^{3}$ とした. コンクリートの運搬にはスクリュー式排出 機のついたバケットを使用して，夏期のスランプドロッ プや格点部の打込み時間の増大に伴うコンクリートの流 動性低下に対処した.この場合には鉄筋やシースが密集 しているため, 片側からコンクリートを流し込む方法を とらないで，一層の打上り高さが $30 \mathrm{~cm}$ 程度になるよ ら水平に2 3 層に分けて打設した. 締固めには棒径 $25,45,55 \mathrm{~mm}$ の内部振動機を使用し, 締固め間隔を 30 $\mathrm{cm}$ 程度として 5 10 秒間締固めた.この配合のコンク リートの締固めには, 振動数を通常より少なめにして振 幅を大きくした方が効果は大きかった.

型枠の取りはずしは脱型直後に行われる仮プレストレ スの導入と部材の取扱いに備えて, コンクリートの強度 が $300 \mathrm{~kg} / \mathrm{cm}^{2}$ 以上であることを確認してから行った。 部材接合面のコンクリートはワイヤーブラシあるいはチ ッピングによって粗面仕上げを行った. 工場内での部材 の運搬や工事現場までの長距離輸送, あるいはオートク レーブ養生などによってひびわれがでる恐れがあったの で，一時的な仮プレストレス を導入した。仮プレストレス の導入は脱型直後に行い, 使 用した PC 鋼材は $\phi 20 \mathrm{~mm}$, $\phi 27 \mathrm{~mm}$ の $\mathrm{PC}$ 鋼棒および $\phi 7 \mathrm{~mm}, \phi 9 \mathrm{~mm}$ の PC 銅線 であって, 配置したシースの 曲線状態によって使い分け た・導入された仮プレストレ ス量は $25 \sim 30 \mathrm{~kg} / \mathrm{cm}^{2}$ であ る.これは自重と取扱㧍よび 運搬中の衝撃によって部材断 面に引張応力が生じないよう に定めたものである.

(5) 運搬
トラス部材の輸送距離は $600 \mathrm{~km}$ を越える長距離輸送 であるので, その運搬にはセミトレーラーと貨車とを使 い分けた. トレーラー輸送した部材は両端の上弦材（約 $12 \mathrm{t}, 14 \mathrm{~m}$ ), 両端の下弦材 (約 $14 \mathrm{t}, 14 \mathrm{~m}$ ) のそれぞれ 28 部材であり, 貨車輸送は中央部の上下弦材（約 $15 \mathrm{t}$, $18 \mathrm{~m}) 24$ 部材である. 重量 $2 \sim 3 \mathrm{t}$ で長さが短い垂直材 および斜材の 304 部材は, 弦材と同時にトレーラーお よび貨車に混載して輸送した.

\section{（6）オートクレーブ養生した超高強度コンクリート の圧縮疲労試験}

トラスのコンクリート部材は列車の通過によって絽り 返し応力を受けるが, オートクレーブ養生した超高強度 コンクリートに関する疲労性状についてはまだほとんど 研究されてないので, 圧縮疲労試験を行ってこの点を検 討した.ここで行った圧縮疲労試験は強度 $800 \mathrm{~kg} / \mathrm{cm}^{2}$ の 円柱供試体 $(\phi 10 \times 20 \mathrm{~cm})$ を使用して, 下限态力度 25 $\mathrm{kg} / \mathrm{cm}^{2}$, 上限忘力度を強度の $90,80,70$ 抢よび $60 \%$ に変 えて疲労破壊までの繰り返し回数を調べたものである.

図一14 はこの圧縮疲労試験の結果である. 図一14 に示 すように，上限応力度が強度の $70 \%$ の場合は $4 \sim 6$ 万 回の繰り返し回数で破壊しているが，60\% の場合は70 ～100 万回と急激に大きくなっている.

通常使用されているコンクリートの 100 万回繰り返 し回数に対する圧縮疲労強度は, 一般に静的圧縮強度の 50〜55\% といわれており, 図一14 に併記した明星大学 の研究成果とも一致している. この圧縮疲労試験の結果 よりすれば, $800 \mathrm{~kg} / \mathrm{cm}^{2}$ の超高強度 コンクリートの圧 縮疲労性状は通常のコンクリートとほとんど同様であっ て, 100 万回の繰り返しにおける圧縮疲労強度は静的圧 縮強度の 55 60\% である. したがって, 表一 3 に示す

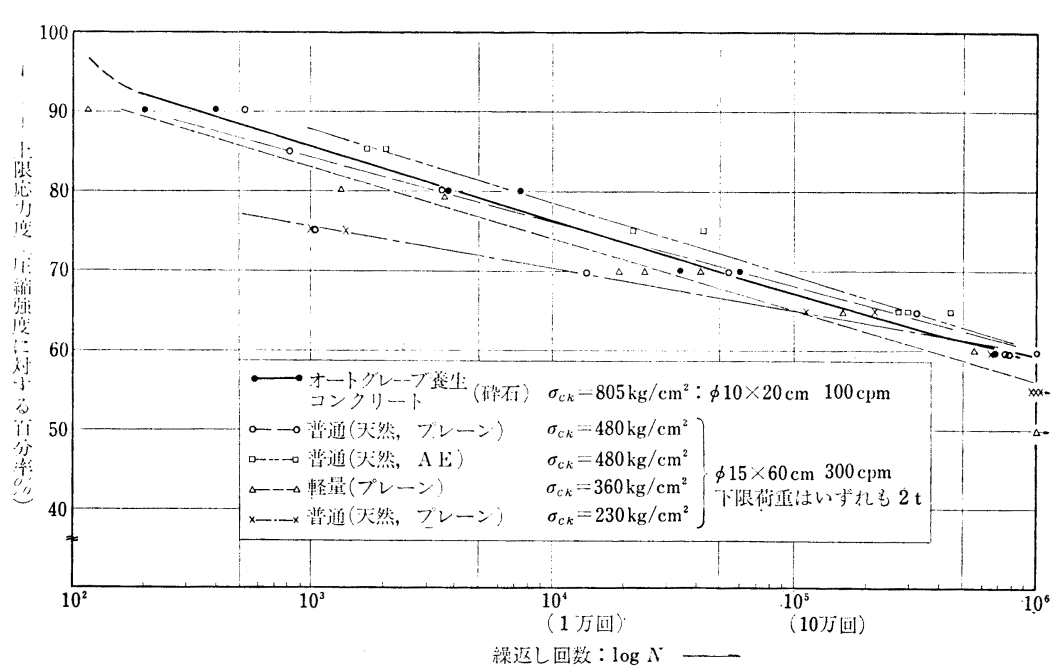

図-14 上限応力度と繰り返し回数の関係 
コンクリートの許容応力度は疲労性状を考えても十分安 全な值であると考えられる.

\section{6. 現場施工}

\section{（1）トラス主構の架設}

橋梁架設地点はトンネルにはさまれた深い峡谷で, 河 床から施工基面までの高さは約 $40 \mathrm{~m}$, 線路の曲線半径 は $700 \mathrm{~m}$, 勾配は 8\% といった非常にきびしい立地条 件となっており，また第 2 径間と第 3 径間は漁場となっ ているため, 支保工その他がつくれないといった作業上 の制約があった。またトラスを構成している最大の部材 の重量は $15 \mathrm{t}$ であり，1組の枠組の重量は $50 \mathrm{t} ， 1$ 連 では $400 \mathrm{t}$ となるようなかなりの重量物になるので,こ

\section{表一9 架設工法の比較}

\begin{tabular}{|c|c|c|}
\hline 架設方法 & 利 & 欠 \\
\hline $\begin{array}{r}\text { ケーブル式 } \\
\text { 架 }\end{array}$ & $\begin{array}{l}\text { 架設地点の諸条件に対 } \\
\text { する適合性が高く，河 } \\
\text { 床を利用する必要がな } \\
\text { い. }\end{array}$ & $\begin{array}{l}\text { 死荷重が大きいためケーブルで } \\
\text { 支えることが困難なうえ，曲線 } \\
\text { 半径か } 700 \mathrm{~m} \text { あるため，ケー } \\
\text { ブルのもりかえが必要となる. }\end{array}$ \\
\hline $\begin{array}{l}\text { 引出し 式 } \\
\text { 架 }\end{array}$ & $\begin{array}{l}\text { 使用架設機械が少なく } \\
\text { 足場も不要である. }\end{array}$ & $\begin{array}{l}\text { 曲線区間のため橋脚にブラケッ } \\
\text { トが必要であり, 架設時応力も } \\
\text { 大きくなる. }\end{array}$ \\
\hline $\begin{array}{l}\text { 唇出し式 } \\
\text { 設 }\end{array}$ & $\begin{array}{l}\text { 架設部材の重量が小さ } \\
\text { く足場も不要である. }\end{array}$ & $\begin{array}{l}\text { 架設時応力が大きく，目地コン } \\
\text { クリートの打設が困難である. }\end{array}$ \\
\hline $\begin{array}{l}\text { 総足場式 } \\
\text { 架設 }\end{array}$ & $\begin{array}{l}\text { 架設時佳力が発生せず } \\
\text { 架設技術は比較的高度 } \\
\text { のものを要しないため } \\
\text { 安全性が高い. }\end{array}$ & $\begin{array}{l}\text { 流水があり河床高に変化の多い } \\
\text { 場合は不適当であり，橋脚が高 } \\
\text { い場合には工費が高くたる. }\end{array}$ \\
\hline
\end{tabular}

れを能率よく取扱うことができるような機械設備が必要 であった.さらにコンクリートトラスといら特殊な構造 であるので，架設時応力が発生するような工法はできる だけ避けたいといら構造上の制約もあった。

トラス主構の架設方法には, 表一9 に示すような工法 が考えられる. 張出し式または引出し式架設方法はトラ スの構造上の利点を生かしたもので, また経済的な工法 であるが，本橋梁は新しい構造形式のものであり，現場 条件も簃しいので, 施工の安全性の大きい総足場引出し 工法によって架設することにした。ここでいう総足場式 引出し工法とは，橋梁中間部の第 4 径間の河川敷につく られた枠組組立ヤードにおいてトラス枠組を組立て，第 4 径間につくられた支保工上まで吊り上げた後に，ここ を引出し基地として順次足場を引出して架設する工法で ある.この架設工法によれば，架設工費の経済性におい ては劣るが, 部材の組立ては容易であり, 組立て精度も よく，架設時応力を考慮する必要がないといった大きな 利点があり，架設工法として最も安全度の高いものであ る.この総足場引出し工法の概要を示すと 図一15 のよ らになる. 以上その各段階の作業について示すことにす る.

\section{（2）トラス枠組の組立}

安家川河川敷に $16.0 \mathrm{~m} \times 75.0 \mathrm{~m}$ の製作ヤードを作 りスパン $16.0 \mathrm{~m}$ の $30 \mathrm{t}$ 吊自走式門型クレーン 2 基 を配置して，枠組の組立て作業を行った。

トラス枠組の組立ては，先に上下弦材を据付けてから 斜材·垂直材の据付けを行ったが，斜材·垂直材の据付け

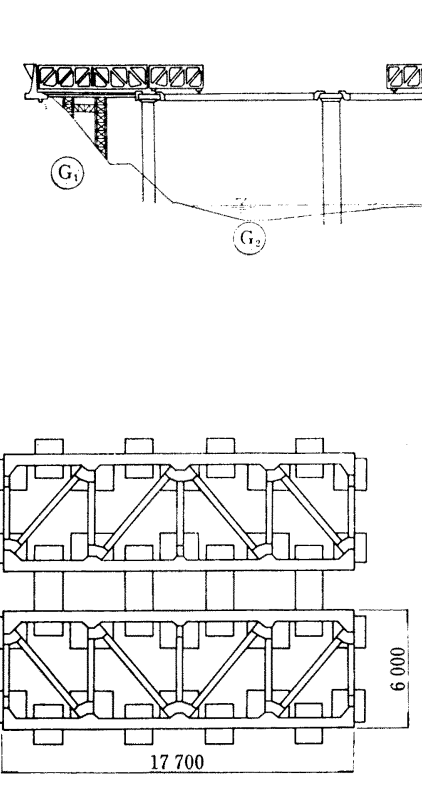

(b) 桃新分裴作:

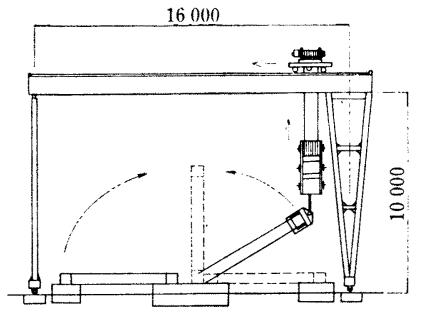

(c) 梢新の引き起

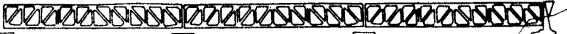

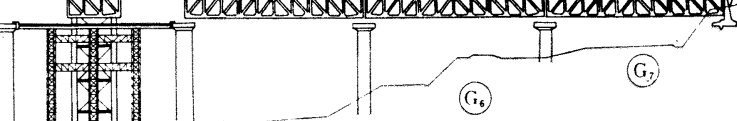

$\mathrm{G}_{1}$

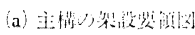

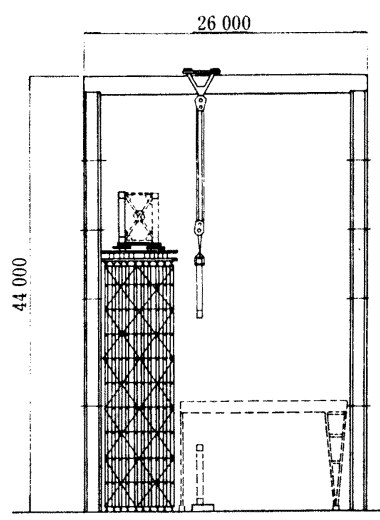


表一10 垂直部材 3-14にプレストレスを槊入したとき のひずみ実測值 $\left(\boldsymbol{s}_{c}\right)$

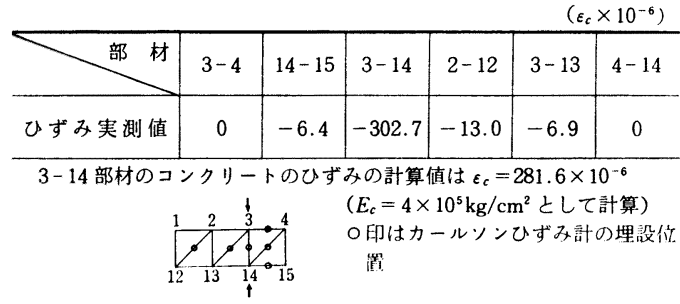

には組立台を利用することによって，能率よく作業する ことができた.枠組の組立て後の平面性の精度は $\pm 7 \mathrm{~mm}$ 程度であった. 垂直材の PC 鋼棒の緊張作業は, 部材に できるだけ 2 次応力を生じさせないようにするため, 緊 張順序を定めて作業を行った. 部材内に埋込まれたカー ルソンひずみ計により，プレストレス導入時の軸方向ひ ずみを測定したが, どの部材にも引張ひずみは認められ なかった. カールソンひずみ計での測定結果は 表一10 のようであり, 垂直材に所期のプレストレスが導入され ていることが確認された.

\section{（3）接合目地コンクリート}

接合目地コンクリートは現場近くの生コンクリート工 場のプラントで練り混ぜたものを使用した。骨材は現地 のものを用いたが，そのコンクリートの配合は太田名部 橋梁での 施工結果を参考にして, 表一11 のように定め た. 表一12,13 は使用材料および強度試験の結果を示し たものであるままた 図一16 に示寸圧縮強度は現場の部

表一11 示方配合 $\left(\sigma_{c k}=600 \mathrm{~kg} / \mathrm{cm}^{2}\right)$

\begin{tabular}{|c|c|c|c|c|c|c|c|c|}
\hline \multirow{2}{*}{$\begin{array}{l}\text { 粗骨材 } \\
\max \\
(\mathrm{mm})\end{array}$} & \multirow{2}{*}{$\begin{array}{c}\text { スランプ } \\
(\mathrm{cm})\end{array}$} & \multirow{2}{*}{$\begin{array}{l}W / C \\
(\mathscr{6})\end{array}$} & \multirow{2}{*}{$\begin{array}{l}s / a \\
(\%)\end{array}$} & \multicolumn{5}{|c|}{ 単位重量 $\left(\mathrm{kg} / \mathrm{m}^{3}\right)$} \\
\hline & & & & $C$ & $W$ & $S$ & G & 減水剤* \\
\hline 20 & $15 \sim 20$ & 30 & 38 & 550 & 165 & 640 & 1097 & $\begin{array}{c}C \times 1.75 \% \\
9.625\end{array}$ \\
\hline
\end{tabular}

表一12 使 用 材 料

\begin{tabular}{|c|c|c|c|c|c|c|}
\hline \multirow{2}{*}{ 材 } & \multirow{2}{*}{\multicolumn{2}{|c|}{ 料 }} & \multirow{2}{*}{ 種 類 産地 } & \multicolumn{2}{|c|}{ 性 } & 空 \\
\hline & & & & 比 重 & F.M & 吸水量 \\
\hline セ & $x \quad y$ & $r$ & 早強ポルトランド & 3.13 & - & - \\
\hline 䊗 & 骨 & 材 & 青森県八戸産川砂 & 2.57 & 2.60 & 2.58 \\
\hline 粗 & 骨 & 材 & 岩手県久慈産碎石 & 2.70 & 6.81 & 1.22 \\
\hline 沎 & 和 & 剂 & 减 水 剂* & 1.21 & - & - \\
\hline
\end{tabular}

表-13 圧縮強度およびャング係数

\begin{tabular}{|c|c|c|c|c|}
\hline \multirow{2}{*}{ 供試体 } & \multicolumn{3}{|c|}{ 压縮強度 $\quad\left(\mathrm{kg} / \mathrm{cm}^{2}\right)$} & \multirow{2}{*}{$\begin{array}{c}\text { 静弾性係数 } \\
E_{c} \\
\left(\mathrm{~kg} / \mathrm{cm}^{2}\right)\end{array}$} \\
\hline & $\sigma_{7}$ & $\sigma_{14}$ & $\sigma_{x}$ & \\
\hline (1) & 511 & 584 & 708 & 416000 \\
\hline (2) & 499 & 574 & 708 & 402000 \\
\hline (3) & - & 631 & 674 & 367000 \\
\hline 平 均 值 & 505 & 596 & 697 & 395000 \\
\hline
\end{tabular}

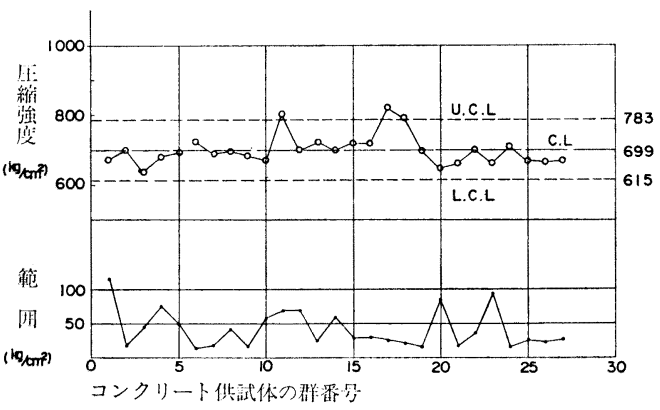

図-16 現場での高強度コンクリートの圧縮強度

材と同じ状態で 24 時間養生し, その後標準養生した供 試体で試験したもので，コンクリートの圧縮強度の平均 值は $699 \mathrm{~kg} / \mathrm{cm}^{2}$, 標準偏差は $44.6 \mathrm{~kg} / \mathrm{cm}^{2}$, 変動係数は $6.4 \%$ である.

\section{（4）トラス枠組の移動}

組立てられたトラス枠組は能力 $30 \mathrm{t}$ の門型クレーン 2 台で引き起こしたが, 引起こし作業中部材に大きな仮 設時応力を生じさせないようにするため, 門型クレーン から吊り下げた 2 台のホイストは連動するようにし, ト ラス枠組との間に吊りビーム 2 本をピン構造で結び, 一 点吊りとなるようにした. さらに，上弦材に取り付ける 吊金具をピン構造とし，下弦材の支持点には厚さ $20 \mathrm{~mm}$ の合成ゴム板を敷いて, 引起こし時の回転と衝撃の緩衝 材とした. なお引起こし作業中に, 上下弦材に引張応力 が発生する恐れがあったので，PC 鋼棒を用いて仮プレ ストレスを導入した.

引き起こしたトラス枠組は, 定置式門形クレーンの下 に一時仮置したのち，第 4 径間上に吊り上げL型鋼を用 いた仮横構, 仮対傾構によって立体トラスを形成させ, 重トロで所定の位置までウインチにより引き出した．こ の仮横組工を設けた目的はトラス枠組の間隔を保持し, 引出し中および引出し後のトラス枠組の転倒を防止し, トラス主構の移動・据付時にも大きな架設時応力が作用 しないようにするためである.

\section{（5）トラス主構の組立}

仮組立された 3 つのトラス枠組は, 所定の位置に据付 けられた後, 接合部の配筋を行い, PC 鋼線を通してか ら，接合目地コンクリート $\left(\sigma_{c k}=600 \mathrm{~kg} / \mathrm{cm}^{2}\right)$ を打設し， プレストレスを導入した. PC 鋼材としては上弦材 1 本 当り OSPA $75 \mathrm{~A}(18-\phi 7 \mathrm{~mm})$ を 2 本, 下弦材 1 本当り OSPA $100 \mathrm{~A}(24-\phi 7 \mathrm{~mm})$ を 8 本用い, 主構の架設作業 の関係で片引き緊張とし, 上弦材, 下弦材の順序で緊張 した. 上下弦材にプレストレスを導入するとき，トラス 自体は短縮すると同時に変形する.プレストレス導入時 の主構短縮量の計算值は $28 \mathrm{~mm}$, 主構のたわみの計算 


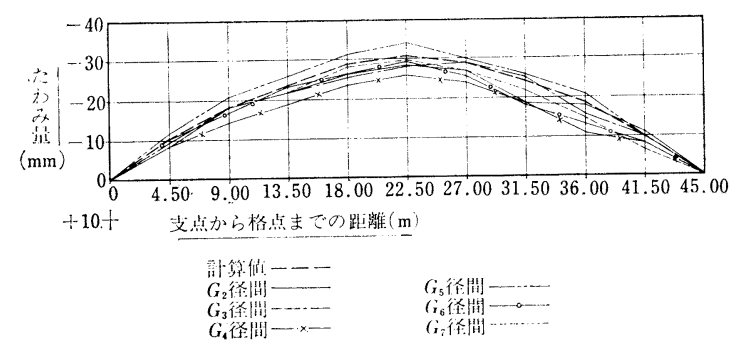

図一17 プレストレスト導入直後（プレストレス+ 主構自重）のたわみ測定值

值は $-33 \mathrm{~mm}$ であるので, 主構の据付け時にはこれら のことを考慮して目地間隔および据付け高さを定めた. 図一17 はトラス主構にプレストレスを導入した直後の たわみの実測値を示したものである.

\section{（6）支承の据付け}

主構にプレストレスを導入する作業空間を確保す るために，構造中心線より $60 \mathrm{~cm}$ 程度ずらした状 態でトラス主構を組立てたので，プレストレス導入 後 $100 \mathrm{t}$ の油圧ジャッキ4 台を用いて縦取りと横取 りを行って, 所定の位置にトラス主構を移動した. 支承にはベアリングプレート沓が用いられたが，下 沓を所定の高さおよび位置に据付けてから, 主構を ジャッキダウンして主構の据付けを完了した.

\section{（7）横桁・耐震壁}

トラス主構が定位置に据付けられた後, 横桁と耐 震壁の配筋を行い，コンクリートを打設した. 上横桁 は，その上にのる床版がプレキャスト床版であるので, 仕上げ面が計画高さとなるように上げ越し量の計算を行 って，その高さを定めた。

\section{（8）床版}

休版は, その施工時期が冬期の厳寒時であり, かつ地 上 $40 \mathrm{~m}$ の高所作業となるため, 現場打ち施工とした場 合のコンクリートの養生が非常に困難となるので, プレ キャスト床版として設計された. 床版のプレキャストブ ロックは, 幅 $5.8 \mathrm{~m}$, 長さ $4.5 \mathrm{~m}$, 重量 $27 \mathrm{t}$ である. 河川敷で製作された床版ブロックを定置式門型クレーン を利用してトラス主構上まで吊り上げ，簡単なワーゲン を用いてその据付けを行った(図一18 参照).トラス 1 連 分の据付けを完了した後, 床版ブロック間の目地コンク

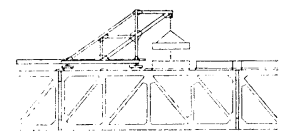

図一18 プレキャスト 床版の架設
リートを打設し, $10 \mathrm{~kg} / \mathrm{cm}^{2}$ 程 度のプレストレスを軸力として 与えた.このプレストレスの導 入には C.C.L 工法を用い, PC 鋼材には $\phi 17.8 \mathrm{~mm}$ の $\mathrm{PC}$ 鋼

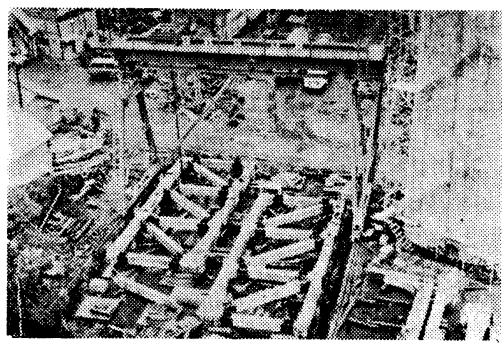

写真一4 プレキャスト部材の組立

より線を使用した。

\section{（9）支保工および機械設備}

支保工としては，架設地点の立地条件と支保工の転用 を考慮して全 7 径間のちち 4 径間分を用意し， 2 径間は

表一14 現 場 工 程

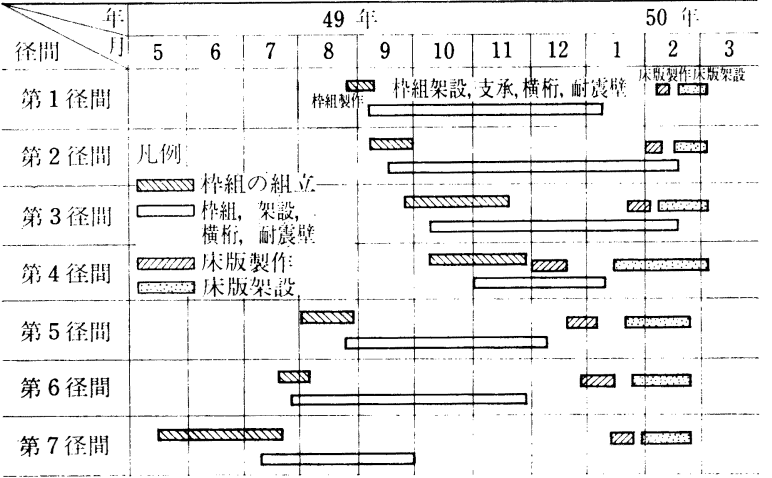

四角支柱とH形鋼を用いた支保工を, 残り 2 径間分は鋼 製の架設桁とした. 引出し基地となる第 4 径間には, 全 工事期間を通じ四角支柱と H形鋼を使用し, その他の径 間の支保工は最初宮古側 3 径間の部分を架設し, その後 久慈側の 3 径間に転用した. 支柱式支保工はトラックク レーンで組み，架設桁は手延べ式で移動架設した．現場 工程表は 表一14 に示すとおりである.

\section{7.あとがき}

（1）本橋梁は, オートクレーブ養生によって工場製 作された超高強度コンクリート $\left(\sigma_{c k}=800 \mathrm{~kg} / \mathrm{cm}^{2}\right)$ のプ レキャスト部材を組立てて, トラス構造を構成したもの で, 長大スパンのコンクリート橋に対しての 1 つの方策 を示したものである．互換性のある工場製作のプレキャ ストコンクリート部材を用いて, 現場施工の容易な横置 き引起こし工法を開発し, これによってトラス主構を組 立てたが，この工法を用いることによって現場でのプレ キャスト部材の接合がきわめて容易に行われ，接合部に 問題が残ることもまったくなかった. またトラス部材の 
ような大型のコンクリート部材をオートクレーブ養生し て作ることができたのも，本橋梁の研究成果によるもの と考えている.

（2）本格的なコンクリートトラスとしては初めての 試みであったため, 施工の安全性を重視して総足場引出 し工法によってトラスを架設したが, 本橋梁のように支 保工の高さが高い場合には工費のかかる工法であった。 今後の問題としては，足場を必要としない張出し架設・ 引出し架設といった工法が问能となるようなコンクリー トトラスの構造を研究する必要があるものと考えられ る.

（3）本橋梁は, トラス部材にできるだけプレキャス トコンクリート部材を使用するといった方針で設計を進 めたため，トラス主構を架設してからその上に床版を施 工するという二段階の工程をとっており，このためトラ ス主構と床版は垂直方向に非合成構造になっている.こ のことは構造的にみても有利なことではなく, 工費的に も高いものについている.プレキャスト部材に対して場 所打ちコンクリートの使用範囲を払げることによって, トラス主構と床版とを一体的に施工寸ることができれ ば，より経済的なコンクリートトラスができるものと考 えられる。

（4）コンクリートトラスは耐久性においても優れて おり，振動・騒音の発生などに対しても鋼橋に比して有 利であるので, 技術的に可能になったこの構造を経済的 に施工する研究を進めることによって, コンクリート橋 の長大化が達成されるものと考えている.

安家川橋梁は, 1970 年に最初の計画が立てられたも ので, その後数回にわたる橋梁会議によって各種形式の 比較設計, 設計方法, 施工方法などの検討が進められ, その成果に基づいて本形式の橋梁の採用が決定されたも のである.したがって, 日本鉄道建設公団の本社および 盛岡支社の関係者ならびに東京大学の平井名誉教授, 国 分名誉教授を始めとする橋梁会議の出席者, 橋梁の設計 を担当した長大橋設計センター(株), プレキャスト部 材の製作を担当した日本コンクリート工業 (株), 現場 での施工を担当したオリエンタルコンクリート(株), 現場測定を行った東京大学交通研究室などきわめて広い 範囲の方々にご指導とご協力をいただいた. 本報告にあ たってこれらの方々に深甚の謝意を表する次第である.

\section{参 考 献}

1）土木学会編：コンクリート標準示方書, 1967.

2）土木学会編：プレストレストコンクリート設計施工指針 (案), 1961 .

3) 日本国有鉄道: 建造物設計標準, 1970 .

4）土木学会 : OSPA 工法設計施工指針 (案), コンクリート ライブラリー，第 31 品, 1972.

5）小川敬次郎：鉄筋コンクリート橋径間長さの世界記録に 就て, セメント界彙報, No. 382, 1940-1.

6）猪股俊司：プレストレストコンクリートトラスに関する 模型試験, プレストレストコンクリート, Vol. 5, No. 2, pp. 26, 1963.

7）斎藤俊彦・草間 一・鈴木真男：PCトラス橋太田名部橋 梁の設計施工について, 土木学会, 第 28 回年次学術溝演 会概要集, 第 1 部, 1973.

8）安井将文・小島法夫 : 安家川PCトラスに関する光弾性 実験, 土木学会, 第 28 回年次学術講演会概要集, 第 1 部, 1973.

9）松本嘉司・西岡 隆・橋本渉一：PCトラス橋の静的動 的試験について, 土木学会, 第 1 回 関東支部年次研究発 表会概要集, pp. 61, 1974-5.

10）斉藤俊彦・草間一：久慈線太田名部橋梁 ( P C トラス橋) の設計施工,プレストレストコンクリート, Vol. 16, No. 4, pp. 5, 1974.

11）近藤時夫 : わが国最初の $\mathrm{PC}$ トラス鉄道橋, セメントコ ンクリート, No. 328, pp. 27, 1974.

12) 斉藤俊彦・滝沢正道: 久慈線安家川橋りょう P Cトラス の施工, セメントコンクリート, No. 336, pp. 27, 1975.

13) CEB-FIP : Recommendations internationales pour le calcul et léxécution des ouvvages en béton, seconde edition, Juin 1970.

14) Through-Cantilever Bridge of Concrete Built in Scotland, Engineering News-Record, pp. 300, August 20, 1931.

15) Nordby, G.M. : Fatigue of Concrete-A Review of Research, Journal of A.C.I, Vol. 30, No. 2, 1958.

16) Finsterwalder, U. : Die neue Mangfallbrücke, Deutschen Beton-Vereins, 1959.

17) Suarez, M.G. : Longer Span Prestressing with PostTensioned Trusses, PCI Journal, pp. 41, Vol. 5, No. 3, 1960.

18) Lossier, M.H. : Présentation cinematographique de cinq ouvrages typiques en béton Précontraint ( 4 . Reconstruction du Pont de Mangfall), Annales de l'Institut Technique du Bátiment et des Travaux Publics, No. 171 172, pp. 386, Mars-Avril, 1962.

19) Vaessen, E.h.F. : Neue rationelle Verfahren im Stahlbetonbau, Der Bauingenieur, Heft 1, S. 4, 1967.

20) Matsumoto, Y., T. Saito, T. Kondo, I. Miura, Y. Mine and T. Maruyama: Precast Prestressed Concrete Truss Railway Bridge using Extremely High Strength Concrete, 10th Congress of IABSE, 1976.

(1971.12.17 · 受付) 